\title{
Tile Drainage on Agricultural Lands from North- East Romania - Experimental Variants and Technical Efficiency
}

\author{
Daniel Bucur and Valeriu Moca \\ University of Agricultural Sciences and Veterinary Medicine in Iasi
}

Romania

\section{Introduction}

Romania is situated in geographical center of Europe (south-east of Central Europe) at north of Balkan Peninsula at the half of distance between Atlantic Coast and The Urals, inside and outside the Carpathians Arch, on the Danube lower course and has exit to the Black Sea. Otherwise, parallel $45^{\circ} \mathrm{N}$ with the meridian $25^{\circ} \mathrm{E}$ intersects near the geometrical center of the country, $100 \mathrm{~km} \mathrm{N-V}$ of the country capital, Bucharest. Romania is the twelfth country of Europe, having an area of 238,391 km².

Romania's relief consists of three major levels: the highest one in the Carpathians, the middle one which corresponds to the Sub-Carpathians, to the hills and to the plateaus and the lowest one in plains, meadows and Danube Delta.

Romania's climate is temperate-continental of transition, with oceanic influences from the West, Mediterranean ones from South-West and continental-excessive ones from the East. Multiannual average temperature is latitudinally different, $8^{\circ} \mathrm{C}$ in the North and over $11^{\circ} \mathrm{C}$ in the South, and altitudinally, with values of $-2.5^{\circ} \mathrm{C}$ in the mountain floor and $11.6^{\circ} \mathrm{C}$ in the plain.

Yearly precipitations decrease in intensity from west to east, from over $600 \mathrm{~mm}$ to less 500 $\mathrm{mm}$ in the East Romanian Plain, under $450 \mathrm{~mm}$ in Dobrogea and about $350 \mathrm{~mm}$ by seaside, in the mountainous areas they reach $1000-1500 \mathrm{~mm}$.

Romanian running waters are radially displayed, most of them having the springs in the Carpathians. Their main collector is the Danube river, which crosses the country in the south on $1075 \mathrm{~km}$ length and flows into the Black Sea (Romanian Statistical Yearbook, 2010).

Maps of Excess of moisture show the geographic occurrence, at national and district level, and intensity of the three kinds of excess of moisture: from groundwater, rainfall and by floods. The classes are defined according to intensity and the subclasses according to the nature (source) of the excess moisture (Munteanu et al., 2004).

Drainage systems reduces the volume of drainage water leaving a field by $20-30 \%$ on average; however, outflow varies widely depending on soil type, rainfall, type of drainage system and management intensity (Ramoska et al., 2011). 
The impact of drainage on yields is variable. Long-term computer simulations indicate that the average annual yield increase is less than $5 \%$, but it could be substantial in some years depending on annual precipitation variability and regional climatic characteristics as well (Cooke et al., 2002, Troeh et al, 2005).

Drainage systems must cost-effectively manage flooding, control streambank erosion, and protect water quality (Lukianas et al., 2006). To do this, designers must integrate conventional flood control strategies for large, infrequent storms with three basic stormwater quality control strategies for small, frequent storms: infiltrate runoff into the soil, retain/detain runoff for later release, and convey runoff slowly through vegetation (Ritzema et al., 1996, Singh et al., 2006).

Integrated flood control/stormwater quality control designs must meet a variety of engineering, horticultural, aesthetic, functional, economic, and safety standards (Townend et al., 2001, Walker et al., 1989).

The preservation and sustainable use of soil resources include also the differentiate application of hydro-ameliorative works depending of the limiting factors of soil fertility.

Monitoring within Romania has revealed that there are approximately 4.0 million ha of farmland that have suitable soil resources, 3.7 million ha of which are arable lands, capable of sustaining competitive agriculture (Dumitru et al., 2004).

According to the Romanian Statistical Yearbook from 2008, the area of agricultural land categories affected by various limiting factors of productive capacity included: frequent droughts - 7,100 thousand ha; periodic excess moisture in the soil - 3,800 thousand ha; soil erosion and landslide - 7,000 thousand ha; soil compaction - 6,500 thousand ha; high and moderate acidity - 3,400 thousand ha; small and very small reserves of humus in soil - 7,500 thousand ha; low and very low concentration of mobile phosphorus - 6,300 thousand ha.

According to the data highlighted by Man et al., 2002, based on specialized studies carried out in the counties of Timis, Arad, Bihor and Maramures, there was estimated an agricultural area of 958,000 ha affected by excessive moisture. On these agricultural lands having excess moisture, there were carried out drainages for 854,925 ha, of which an area of 18,159 ha was drained with tile and plastic drains.

The spatial distribution of the ecosystemic territorial units in north-east of Romania, respectively, in Suceava County, showed a percent of soil with excess moisture ranging between $30 \%$ and $40 \%$ of the considered area, with an extension from south to north and from east to west. According to data estimated by Moca et al., 1988, 2001, the permanent and / or temporary excess moisture has been present over time on a area of more than 100,000 ha. Among the hydro-ameliorative improvements performed on agricultural lands with excess moisture in the extra-Carpathian region of Suceava County, there can be mentioned the drainage systems with open canals, and in some areas includes also subsurface drainage provided with ceramic and/or plastic pipes. The management of soil resources having excess moisture and a high risk of suitability for agricultural use requires the use of photogrammetric products as images and digital data files.

Suceava County is situated in the north part of Romania and is included, together with other five counties, in the North-Eastern Development Region. Having a total area of 855,350 ha, Suceava County is the second largest county of Romania, representing $3.6 \%$ of the country 
surface. By land use, Suceava County has 349,544 hectares agricultural land, representing 41 $\%$ of the total surface, and 505,806 ha, i.e. $59 \%$, non-agricultural land (Jitareanu et al., 2009).

The resources of agricultural land of Suceava County are limited both by the size of the contained area, and by production capacity. With the aim of normal use of soil resources, a series of hydro-ameliorative works have been done over time. The goal of performing these works was to combat the following soil agricultural capacity limiting factors: excess moisture, flooding risk, soil erosion, unstable slopes and others.

Among the first works to eliminate the water excess, which were applied on the agricultural land with excess moisture in Bucovina can be mentioned: surface water drainage channels between the parcels of different owners; land forming in the bedding system with ridges and furrows; canals for water evacuation and others. Documents from that time show that the first ameliorative works associated with drainage works were performed in the late nineteenth century and early twentieth century in Radauti Depression, by the Agricultural Society of Vienna, who executed both, subsurface drainage and small regularization of rivers. Starting with 1895 and then between 1903 and 1910, was done a series of important tile drainage works in Radauti Depression.

The drainage and subsurface drainage works included several development stages, which took place, particularly between 1950 and 1990. In the first stages, from 1950 to 1975, were designed drainage systems and river regularization with dikes. In the second period that ranges between 1976 and 1990, some older systems were improved and resized. Also, in some hydrographic basins were executed new works, which included the hydroameliorative systems with canal drainage and subsurface drainage.

In the social and economical context of Romania after 1990, which led to a substantial decline of investments, land improvements were, also diminished. At this stage, was done only maintenance work and completion of existing improvements. Among the specific works carried out during 1990-2010 can be mentioned: the maintenance of drainage ditch networks, pipe and tile drains and flood prevention works.

In Suceava County, surface drainage systems were set up on 55,100 ha, tile drainage networks on 26,300 ha and systems of embanking and protection against floods on 7,400 ha between 1960 - 1990 to remove this excess moisture.

The structure of land use types from Suceava County, which includes a share of agricultural land of $41 \%$ and $53 \%$ for forests and forest plantations, is relatively balanced for a territory belonging to the Carpathian orogeny and the plateaus unit.

Highest soil resources belong to the class of Luvosols, which has a share of $25.3 \%$ from the effectively charted area and among the soil types, can be, and noted the faeoziom with $18 \%$.

The distribution of soil resources on the five quality categories indicates that most of them are included in the III-rd class (35\%) of soils with average fertility, and in the IV-th class (30 $\%)$ of soils with low fertility.

The main limiting factors for soil quality are as follows: excess moisture affecting 185,316 ha, water erosion and land sliding, compaction, acidity and nutrients deficiency. 


\section{Surface and pipe drainage systems}

Natural drainage of the soil is represented by all conditions of terrain, soil and hydrogeology of an area which causes gravity circulation of water located at a point in excess of the land surface or on soil profile (Mirsal et al., 2004).

In terms of hydroameliorative works, the drainage is all that apply to land surface or underground, from which excess water is eliminated.

Surface drainage works is the ensemble of hydro-ameliorative works which removes excess water from rainfall, land surface or accumulated stagnant at the top of the soil profile, above the hard permeable horizons.

From surface drainage category of works are highlighted the following:

- land shaping in slope that is done, usually with a continuous slope of the land surface after one or more inclined planes, to a gutter or nearest canal drainage network. The purpose of levelling land drainage works is to avoid stagnation of rainwater on the surface of local depressions without drainage.

- land shaping in the bedding system with ridges and furrows is the realization of the greatest slope of the terrain of ridges with widths of 15 to 40 min length from 100 to $500 \mathrm{~m}$ and cross slope of $1-3 \%$. These strips are ridges separated by shallow channels with large slopes, easily traversed by agricultural machinery.

- mole drainage consists of galleries of 8 to $14 \mathrm{~cm}$ diameter, located at a depth of 0.4 to 0.8 $\mathrm{m}$ below surface, and is achieved through a special device. The purpose of these underground galleries is to remove excess water from the upper soil profile derived from precipitation.

- deep loosening of soil profile at depth of 0.4 to $0.8 \mathrm{~m}$ is achieved either by plowing or scarifying, to increase the permeability of poorly permeable horizons and infiltration of water into deeper layers of soil profile. In addition to the categories of works mentioned above, surface drainage is completed through a hydropower scheme including collection network channels, outlet channels and all related construction.

- ridge ditch issued for the collection and removal of water from precipitation which is in excess of the land surface.

- drainage ditch is a channel that takes discharged water from the network channels and transports it to the nearest outlet channel being carried long distances between them, from 200 to $500 \mathrm{~m}$.

- evacuation channel is the channel that takes drained water from discharged channels and transports it to the nearest outlet higher point channel or direct in the emissary.

- emissary (water course) is a natural watercourse, in which the drainage system discharges its drained water volume either by gravity or by pumping.

Pipe drainage systems with pipes is represented by all hydro-ameliorative works used for lowering groundwater levels at the depth required by the grown plants, respectively, of climate and soil conditions (Mejia et al., 1998). In this category of work is a contained tubular drain of different sizes, network channels and exhaust collection related construction, filled sometimes with surface drainage. 


\subsection{The causes of excess moisture on agricultural land}

The main water sources and factors that determine the formation of excess soil moisture conditions in Romania are the following:

- $\quad$ precipitation is directly or indirectly, the main source of excess water in the soil for most agricultural land. In natural conditions of various climatic zones are recorded variations of rainfall, both from a calendar year to another, and in the same year from one season to another. Thus, in the same climate area $800-1000 \mathrm{~mm}$ annual rainfall can be recorded in rainy years and only $350-450 \mathrm{~mm}$ in dry years. However, large amounts of precipitation are recorded in short intervals. Thus, in intervals from 1 to 5 consecutive days, rainfall totals from 50 to $150 \mathrm{~mm}$ and sometimes even more. Excess moisture coming from rainwater accumulates in the roots of crops, and sometimes as a layer on top of pedophreatic soil profile. Depending on local natural conditions, excess moisture coming from precipitation is associated with lower slopes and/or local minor unevenness respectively, with clay soils, poorly permeable.

- $\quad$ high water table fed by precipitation, infiltration from river sand other sources contribute to excess moisture on the land of meadows, plain sand low terraces. Excess moisture is manifested by increasing the water table, flooding the area of plant roots as well as small swamps in depression areas. On this land, ground water is usually located at depths between 1 and $5 \mathrm{~m}$, which during rainy or high levels in rivers, lakes and other sources increases almost to the ground surface.

- the heavy rainfall and high ground water level, easy accessional, fuelled by one or more of the above sources, also contribute to the formation of excess moisture on the clay soils, hardly permeable. Excess moisture in the form of swamps and/or caused by precipitation of pedophreatic layer, respectively, as a high ground water level, the result of association between water sources said.

- $\quad$ river water formed by the outpouring of excess moisture and flooding over the sides of valleys without mills. Floods are recorded normally during winter due to snow melting and in summer after heavy rainfall. Duration and frequency of flooding on local conditions vary from one stream to another, very different durations of time. Typically, floods are more frequent and shorter periods on the rivers of Romania and have a longer character and are less frequently in the Danube meadow. However, low lands are flooded from surface water runoff from higher areas of the surrounding land.

- the landscape favours the formation of excess moisture in the soil so the small slopes of the terrain and the local minor unevenness elements which make the water flow and natural drainage of the soil characteristic. These areas are specific areas of meadow and low plains and sometimes on the terraces. Excessive wetting of the soil favours swampiness of the land, especially in humid and subhumid climates.

- the illuvial clay soil with low permeability from wet climate and sub-humid areas are also challenging conditions for gravity circulation of water in the profile. The presence of textural horizon, illuvial clay, hard permeable, at a depth of $60-80 \mathrm{~cm}$ from ground surface contributes to the accumulation of excess water in the upper horizons of the soil profile.

\subsection{Soil water balance}

Agricultural land drainage fitting sizes, in general, for non-permanent or permanent regime, depending on soil water balance, respectively, of the elements considered for calculation of specific flow discharged through drains network. 
Depending on the causes of formation of excess moisture in the soil which were previously presented, the most representative and most common cases encountered in practice of drainage work are.

- Temporarily excess moisture with stagnant nature, caused by precipitation, is specific to farm land with small slopes and local unevenness in humid and subhumid climates with clayey soils hardly permeable. The water balance during periods of excess moisture has the following form:

$$
\mathrm{P}-\mathrm{ET}>\mathrm{S}+\mathrm{I}+\mathrm{W}_{\max }
$$

where:

$\mathrm{P}$ - average annual rainfall;

ET - average annual evapotranspiration;

$\mathrm{S}$ - surface water drainage of land;

I - the amount of water infiltrated in the soil profile, below the plant roots;

$\mathrm{W}_{\max }$ - the maximum amount of water that can accumulate in the soil in the plants root zone.

In practical terms, this formula in a simplified form of soil water balance equation is complete in terms of knowledge of natural factors causing excess moisture in the soil and established necessary drainage work.

In this case, the excess water volume (Ve) can be expressed by the relationship:

$$
\mathrm{Ve}=\mathrm{P}-\mathrm{Et}-\mathrm{S}-\mathrm{I}-\mathrm{W}_{\max }
$$

Specific agricultural land of humid and sub-humid climates are located on terraces, high and piedmont plains, highlands and hills: Banat, Crisana, Maramures, Transylvania and the northern Oltenia and Muntenia. However, large areas have been reported in the subCarpathian hills of Moldova and in the hard permeable soils of Romanian.

- Excess moisture caused by free level ground water, fed from precipitation, infiltration from rivers, lakes, fish ponds, rice facilities, leaking underground and sometimes loss of irrigation water.

Water balance during periods of excess moisture relation is expressed as:

$$
\mathrm{P}+\mathrm{Inf}+\mathrm{Ir}-\mathrm{Et}>\mathrm{S}+\mathrm{I}+\mathrm{W}_{\max }
$$

where:

$\mathrm{P}$ - average annual rainfall;

Inf - infiltration from rivers, lakes and other sources;

Ir - loss of water from irrigation systems;

ET - average annual evapotranspiration;

$\mathrm{S}$ - surface water drainage of land;

I - the amount of water infiltrated in the soil profile, below the plant roots;

$\mathrm{W}_{\max }$ - the maximum amount of water that a soil can accumulate in the plants root zone.

In this case, the excess water volume (Ve) is the appropriate minimum amount of porosity of aeration required for normal respiration of plant roots, respectively, of aerobic microorganisms. 
Agricultural land with excess moisture from the category of soil water balance are commonly encountered in the irrigated or unirrigated territories from the Romanian Plain, more specific soils with good permeability ( $\mathrm{K}>0.5 \mathrm{~m} /$ day). These soils are formed on loess and sandy deposits where the water table is located at medium depths, less than 2-4 $\mathrm{m}$.

- Excess humidity caused by rain and ground water with high, slightly ascending level, supplied from precipitation, infiltration from rivers, lakes, fish ponds, rice facilities, underground leaking and others, in low permeable clay soil conditions. Water balance during periods of excess moisture is obtained by the relation:

$$
\mathrm{P}+\mathrm{Af}-\mathrm{Et}>\mathrm{S}+\mathrm{I}+\mathrm{W}_{\max }
$$

where:

$P$ - average annual rainfall;

Af - water intake from the phreatic layer under pressure;

ET - average annual evapotranspiration;

$S$ - surface water drainage of land;

I - the amount of water infiltrated in the soil profile, below the plant roots;

$\mathrm{W}_{\max }$ - the maximum amount of water that soil can accumulate in the plants root zone.

The agricultural land with this type of moisture excess is common on low land in the Banat, Crisana and Maramures, in internal river meadows and some areas in the Danube.

After the estimated forecast by National Meteorological Administration in the coming years is likely to increase the size of the droughts that will occur in alternation with periods of intense rainfall. During relatively short periods of heavy rainfall, flooding will occur quickly in river meadows with different intensities inside and manifestation of excess moisture in the soil.

The effect of increasing average temperatures predicted for the coming years is considered to be more pronounced in areas of the Romanian Plain and less significant in submountainous and mountainous areas of the Carpathian chain.

\section{Experimental drainage site - Baia depression}

Water excess in soil is a complex process that is determined by some factors like water uptake, circulation and removal in the system soil-subjacent rock. For removing water excess from soil profile, drainage systems were planned for improving soil aeration regime and field cultivation.

For knowing the long-term effect of hydro-ameliorative and soil-ameliorative works, applied under conditions of soil from drainage fields arranged in Baia, was determined the evolution of main eco-soil indicators of unimproved and improved soils.

\subsection{Soil genetic conditions}

The Baia Depression is located in the Sub-Carpathian Basin of the Moldova River, which is located in Suceava County, Romania. The total area of the Baia Depression is approximately 15,000 ha, 5,000 ha of which have excess soil moisture owing to rainfall or groundwater capillary rise. 
The Baia Drain Field has an area of 3 ha and is located on a terrace platform of the Moldova River. The area bends slightly to the southeast and has a longitudinal slope of $2-5 \%$ and a height of $393 \mathrm{~m}$. The parental material is silty clay with a thickness of $10-15 \mathrm{~m}$. As a result, the natural drainage of the soil is weak to very weak. In addition, the groundwater is situated at a mean depth of $9-10 \mathrm{~m}$, and the perched water table is located at a mean depth of $0.2-0.5 \mathrm{~m}$.

The climate of the study area is continental temperate, with great thermal amplitude and rainfall that occurs primarily in the vegetative season. The rainfall in the study area is generally spread non-uniformly and usually torrential. The mean multiannual temperature from 1978 - 2008 was $7.9{ }^{\circ} \mathrm{C}$, the average rainfall was $806 \mathrm{~mm}$ and the average evapotranspiration was $599 \mathrm{~mm}$, with an average water excess of $207 \mathrm{~mm}$.

The vegetation in the study area was composed of a hygrophilous environment that contained an association of Agrostis tenuis and a sub-association of Deschampsia caespitosa, Juncus effuzus, and Carex sp.

Evaluation of the study location revealed that the area was characterized by albic stagnic glossic Luvosol under the Romanian System of Soil Taxonomy (Florea et al., 2003) or albeluvisol under the World Reference Base for Soil Resources (WRB, 2006).

\subsection{Tile drainage experimental variants}

To optimize the air and water regime of soil in the area, an experimental field containing a tile drainage system designed to remove excess water was constructed in 1978.

During the study period (1978 - 2010), six different tiles drainage systems (A, B, C, D, E, F) were installed and the effect of the removal of excess moisture from the soil by these systems was evaluated (Figure 1).

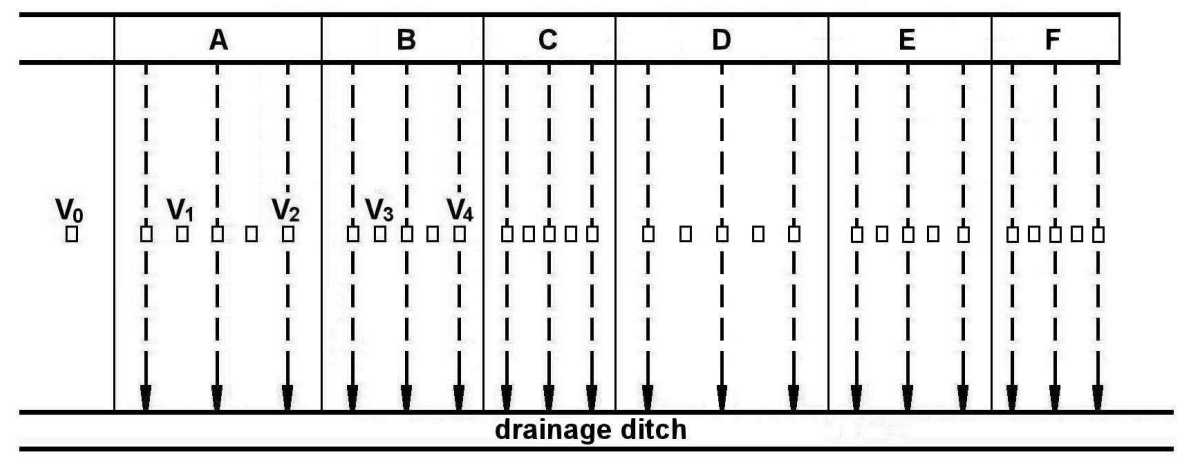

A, B, ... Tile drainage variants

$\longrightarrow$ Drain line

$\square V_{0}, V_{1}, \ldots$ Soil profile at depth of $0-65 \mathrm{~cm}$

Limit of the tile drainge variants

Fig. 1. Hydrotechnical scheme of the Baia drainage experimental site. 
Moreover, in variant $\mathrm{A}$, the tile drainage was combined with the land forming in the bedding system with ridges and furrows. In this variant, furrows were constructed upon tile drains with spacing at $20 \mathrm{~m}$. The bedding turning furrows to the middle of a cut to form a ridge that gradually slopes toward deep furrows to ensure good drainage.

Each drainage variant includes three drain lines. The length of each drain was $100 \mathrm{~m}$ and the slope of the drain lines was $0.2 \%$.

In variants $A, B$ and $C$ the depth of the tile drains is $1.0 \mathrm{~m}$. The spacing between drains is 20 $m$ in variant $A, 15 \mathrm{~m}$ in $B$ variant and $12 \mathrm{~m}$ in $C$ variant. In variants $D, E$ and $F$, the depth of the tile drains is $0.8 \mathrm{~m}$. The spacing of the drains is $20 \mathrm{~m}$ in variant $\mathrm{D}, 15 \mathrm{~m}$ in variant $\mathrm{E}$ and $12 \mathrm{~m}$ in variant $\mathrm{F}$.

Hydrotechnical scheme of the Baia drainage experimental site (Figure 1) was sized to optimize the basic design elements, used routinely in the design of tiles drainage systems (Table 1).

\begin{tabular}{|c|c|c|c|c|}
\hline $\begin{array}{c}\text { Tile } \\
\text { drainage } \\
\text { variant }\end{array}$ & $\begin{array}{c}\text { Spacing } \\
\text { between } \\
\text { drain lines } \\
\text { / depth drain } \\
\text { (m) }\end{array}$ & $\begin{array}{l}\text { Drain } \\
\text { line } \\
\text { number }\end{array}$ & $\begin{array}{l}\text { Pipe type and diameter } \\
\qquad(\mathrm{mm})\end{array}$ & $\begin{array}{l}\text { Type and thickness of } \\
\text { complex drain + filter }(\mathrm{cm})\end{array}$ \\
\hline A & $20 / 1,0$ & $\begin{array}{l}1 \\
2 \\
3\end{array}$ & $\begin{array}{c}\text { Tile } \varnothing 70 \\
\text { Tile } \varnothing 125 \\
\text { Tile } \varnothing 70\end{array}$ & $\begin{array}{c}\text { Ballast (20) + Flax stems (50) } \\
\text { Ballast (70) + Green sods } \\
\text { Ballast (20) + Green sods }\end{array}$ \\
\hline B & $15 / 1,0$ & $\begin{array}{l}4 \\
5 \\
6\end{array}$ & $\begin{array}{l}\text { Tile } \varnothing 70 \\
\text { Tile } \varnothing 70 \\
\text { Tile } \varnothing 70\end{array}$ & $\begin{array}{c}\text { Flax strains (30) } \\
\text { Ballast (12) + Flax stems (20) } \\
\text { Ballast (15) + Green sods }\end{array}$ \\
\hline C & $12 / 1,0$ & $\begin{array}{l}7 \\
8 \\
9\end{array}$ & $\begin{array}{c}\text { Corrugated plastic } \varnothing 65 \\
\text { Smooth plastic } \varnothing 63 \\
\text { Tile } \varnothing 70\end{array}$ & $\begin{array}{l}\text { Ballast (12) + Green sods } \\
\text { Ballast (12) + Green sods } \\
\text { Ballast (15) + Green sods }\end{array}$ \\
\hline $\mathrm{D}$ & $20 / 0,8$ & $\begin{array}{l}10 \\
11 \\
12\end{array}$ & $\begin{array}{c}\text { Corrugated plastic } \varnothing 65 \\
\text { Smooth plastic } \varnothing 110 \\
\text { Tile } \varnothing 70\end{array}$ & $\begin{array}{c}\text { Ballast (20) + Flax stems (40) } \\
\text { Ballast (60) + Green sods } \\
\text { Ballast (20) + Green sods }\end{array}$ \\
\hline E & $15 / 0,8$ & $\begin{array}{l}13 \\
14 \\
15\end{array}$ & $\begin{array}{l}\text { Tile } \varnothing 70 \\
\text { Tile } \varnothing 70 \\
\text { Tile } \varnothing 70\end{array}$ & $\begin{array}{c}\text { Flax strains (30) } \\
\text { Ballast (12) + Flax stems (20) } \\
\text { Ballast (15) + Green sods }\end{array}$ \\
\hline $\mathrm{F}$ & $12 / 0,8$ & $\begin{array}{l}16 \\
17 \\
18\end{array}$ & $\begin{array}{c}\text { Corrugated plastic } \varnothing 65 \\
\text { Smooth plastic } \varnothing 63 \\
\text { Tile } \varnothing 70\end{array}$ & $\begin{array}{l}\text { Ballast (12) + Green sods } \\
\text { Ballast (12) + Green sods } \\
\text { Ballast (15) + Green sods }\end{array}$ \\
\hline
\end{tabular}

Table 1. Materials used for construction of the Baia drainage experimental site.

- Spacing between drain lines: $20 \mathrm{~m}$ (variants A and D), $15 \mathrm{~m}$ (variants B and E) and $12 \mathrm{~m}$ (variants $\mathrm{C}$ and $\mathrm{F}$ ) were determined assuming a non-permanent flow regime.

In terms of functional efficiency, the spacing between drain lines, should allow lowering the groundwater level from the maximum height to optimum height, within 
3-5 days. This lowering of groundwater level in time guaranteed certain plant root zone aeration.

- The depth of the tile drains: $\mathbf{1 . 0} \mathbf{~ m}$ (A, B and C variants), $\mathbf{0 . 8} \mathbf{~ m}$ (variants D, E and F) was sized taking into account the horizontal position of the hard permeable soil profile. If the soil is albic stagnic - glossic Luvosol, the $\mathrm{Bt}_{1} \mathrm{~W}$ textural horizon is located at a depth of 0.9 to $1.0 \mathrm{~m}$.

- $\quad$ Pipe type and diameter that was used for the construction of all 18 drain lines included the following materials: tile drain (pipe are from ceramic) with inner diameter of $70 \mathrm{~mm}$ and $125 \mathrm{~mm}$, tube length of $33 \mathrm{~cm}$ with circular inner section and outer section of hexagonal form, smooth plastic drain with external diameter of 63 and $110 \mathrm{~mm}$; corrugated plastic drains with linear waves and external diameter of $65 \mathrm{~mm}$.

- Filter material that was put on top and around the drainage tube consisted of the following: river ballast, and, for some certain drain lines Ballast with flax strains and vegetal soil on the form of green sods.

Under Romania natural conditions the ballast from the river inland meadows is considered al widely used material as a filter in tube drainage works. Filter layer of Ballast has very good drainage effect because of the maintenance of its permeability over the period of operation of the drainage system. Ballast placed around and above the drainage pipes does not compact under soil conditions; it is not degraded by microorganisms in the soil or groundwater chemical action.

Implementation of drainage tubes was performed using E.T.T. 202-A equipment, a mechanic system that performed: digging trenches with a width of $50 \mathrm{~cm}$, variable depth of $0.8-1.5 \mathrm{~m}$ and laying Tile drainage pipes and / or plastic.

After estimating the cost value of the lei / ha, on the time of implementation of drainage experimental variations has resulted some differentiate constructive solutions. For drain lines: 11/variant D, 2/variant A was the highest assessed values of the cost. Lower cost price values were obtained for the drains: 13/variant $E$ and 12/variant $D$, depending on dimensional elements and building materials used.

\subsection{Improvement procedures}

After installation of the tile drainage system, the study area was used for farming.

The drained soil was then improved by applying the three following experimental cycles:

- Cycle 1 (1978-1986): superficial land forming, cultivation of virgin hygrophilous meadow, deep loosening to a depth of $0-70 \mathrm{~cm}$, amendment by the application of 10 $12 \mathrm{t} \cdot \mathrm{ha}^{-1}$ limestone with a content of $95-100 \% \mathrm{CaCO}_{3}$, organic fertilizing with $40 \mathrm{t} \cdot \mathrm{ha}^{-1}$ manure (in variants A, B, C, D, E and F), land forming in the bedding system with a ridge and furrow (only in variant $\mathrm{A}$ ) once a cycle and annual mineral fertilization (in all variants);

- $\quad$ Cycle 2 (1987 - 1997): deep re-loosening at the useful depth of 0 - $70 \mathrm{~cm}$, re-amendment of the soil with $7-8 \mathrm{t} \cdot \mathrm{ha}^{-1}$ limestone, organic refertilization with $40 \mathrm{t} \cdot \mathrm{ha}^{-1}$ manure once a cycle and annual mineral fertilization;

- $\quad$ Cycle 3 (1998 - 2010): no application of soil improvement and/or cropping works. 
Crop rotations and plants were cultivated in the following three experimental cycles:

- Cycle 1, crop rotation I: maize-two-row barley-potato-flax fibers (1979 - 1982); crop rotation II: (wheat + rye), (maize + potato), maize - potato (1983 - 1986);

- Cycle 2, mixture of seeded perennial grasses (70\%) and legumes (30\%) (1987 - 1990); mixture of perennial grasses (70\%) and overseeded legumes (30\%) (1990 - 1997);

- $\quad$ Cycle 3, overseeded natural meadow (1997 - 2010).

To quantify the changes in the major physical and chemical characteristics of the improved soil in response to the following variations of the drainage treatments described above (Figure 1), at the end of each cycle soil samples from the following treatments were analysed:

$\mathrm{V}_{0}$ - control variant, natural unimproved meadow (Figure 2);

$\mathrm{V}_{1}$ - tile drainage combined with land forming in the bedding system variant: top of ridges (Figure 3);

$\mathrm{V}_{2}$ - tile drainage combined with land forming in the bedding system variant: drain line furrow cross-section (Figure 3);

$\mathrm{V}_{3}$ - tile drainage variant: middle of the drain lines (Figure 4);

$\mathrm{V}_{4}$ - tile drainage variant: drain line cross-section (Figure 4).

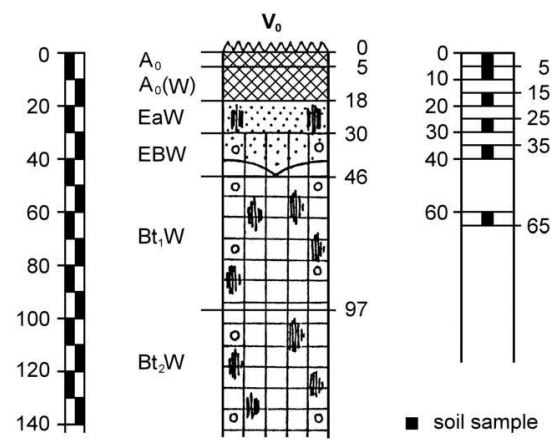

Fig. 2. Soil sampling in the control variant $\left(\mathrm{V}_{0}\right)$.

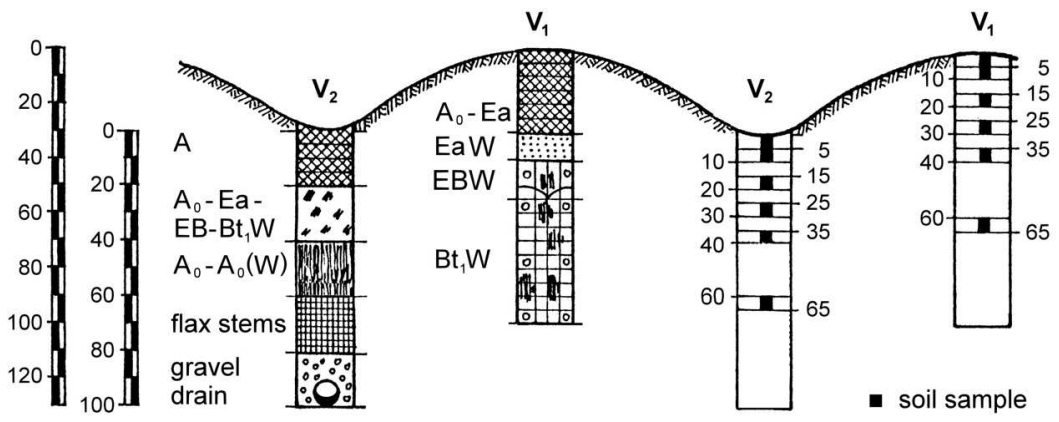

Fig. 3. Tile drainage combined with the bedding system variant - top of ridges $\left(\mathrm{V}_{1}\right) /$ furrow $\left(\mathrm{V}_{2}\right)$. 
The evolution of some physical and chemical features under the influence of the improvements was also analyzed in the three experimental cycles. To accomplish this, soil samples were collected from the ploughed stratum $(0-20 \mathrm{~cm})$ and the horizon below this layer $(20-40 \mathrm{~cm})$. Soil samples were collected using an agrochemical drill at the end of each experimental cycle in 1986, 1997 and 2010 from the entire surface of the experimental variants $\left(\mathrm{V}_{0}, \mathrm{~V}_{1}\right.$ and $\left.\mathrm{V}_{3}\right)$.
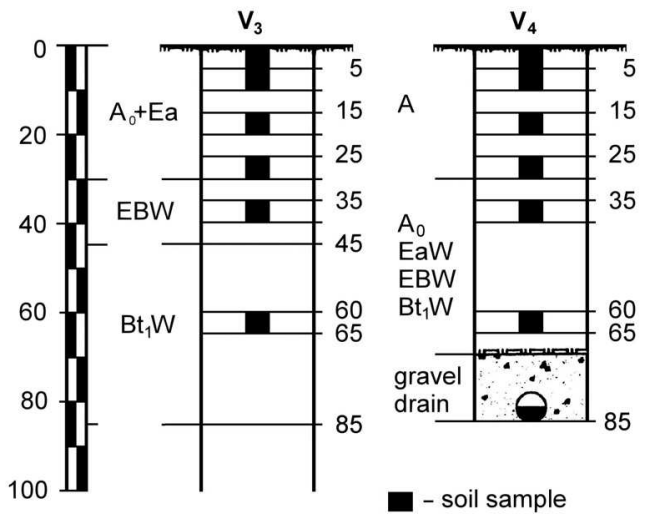

Fig. 4. Tile drainage variant - middle of the drain spacing $\left(\mathrm{V}_{3}\right)$ and drain cross-section $\left(\mathrm{V}_{4}\right)$.

In the natural conditions of this wetland, the albic stagnic - glossic Luvosol, which is used as a natural pasture, presented the following morphological features in the horizon succession (Figure 2):

A $_{0} \quad 0-5 \mathrm{~cm}$ - strongly unreclaimed stratum; silt loam; very dark brown grey $10 \mathrm{YR} 4 / 2$ (wet) and light grey 10 YR 7/2 (dry); small polyhedral angular structure, moderately developed; very friable in wet state, quite hard in dry state; weakly plastic; weakly adherent; very frequent roots.

$\mathbf{A}_{0}$ (W) 5 - $18 \mathrm{~cm}$ - silt loam; dark greyish brown 10YR 4/2 (wet) and light greyish brown 10YR 6/2 (dry); small polyhedral angular structure, moderately developed, friable in wet state and easily compacted when dry; weakly plastic; weakly adherent; frequent coarse and medium pores; thin and very thin frequent roots; clear contact with the horizon below.

E $\mathbf{W} \quad 18$ - $30 \mathrm{~cm}$ - silt loam; light olive colour 7.5Y 6/2 with small yellowish brown spots 10 YR 6/6 (wet) and white 7.5 Y 8/2 with yellowish brown mottles 10 YR 6/8 (dry); small polyhedral angular up to lamellar structure, weakly developed, friable in wet state and easily compacted when dry; weakly plastic; weakly adherent; frequent medium pores; rare very thin roots; diffuse irregular contact with the horizon below.

E+BW 30 - $46 \mathrm{~cm}$ - clayey loam; greenish gray 5GY 6/1 with small and medium frequent mottles, light yellowish brown 10 YR 6/4 (dry) and white 7.5 Y 8/1 with brown yellowish spots 10 YR 6/6 (dry); medium polyhedral angular structure, moderately developed; clay films on the faces of structural aggregates; small and medium ferromanganese spots and concretions; tough when wet and compacted in dry state; plastic; adherent; frequent pores; diffuse irregular contact with the horizon below. 
$\mathbf{B t}_{1} \mathbf{W} \quad 46$ - $97 \mathrm{~cm}$ - loamy clay, greenish gray 5GY 6/1 with frequent large yellowish brown mottles 10 YR 5/6 (wet) and light gray 7.5 Y 7/1 with light yellowish brown 10 YR 6/4 and brown-yellowish 10 YR 6/6 mottles (dry); large prismatic structure, moderately developed; coarse clay films on the faces of the structural aggregates; medium ferromanganese spots and concretions; hard in wet state and very compacted when dry; plastic; adherent.

Following placement of the tile drainage system, land was forming in the bedding system and then the soil was cultivated for the first time. In consequence, a mixture between the upper genetic horizons of the soil profile was observed. After the first experimental cycle (1978-1986), the soil from the surface formed in the bedding system presented the following horizon succession (Figure 2 and Figure 3):

$\mathbf{A}_{0}+\mathbf{A}_{0}(\mathbf{W})+\mathbf{E}_{\mathbf{a}} \mathbf{W}-(0-30 \mathrm{~cm})$ : silt loam;

EaW - 30-40 cm: silt loam;

Ea+BW - 40 - $55 \mathrm{~cm}$ : clayey loam;

$\mathbf{B t}_{1} \mathbf{W}$ - 55 - 97cm: loamy clay.

In the new conditions of the improved soil, the active physiological depth was greater than that in the unimproved soil. The succession of the horizon morphology revealed that the $\mathrm{Bt}_{1} \mathrm{~W}$ textural horizon is situated at a higher depth when compared to the unimproved soil.

The experimental parcels from the space between the drain lines also showed a mixture of the soil profile upper horizons. The changes inferred were signalled in the depth of the ploughed horizon $(0-30 \mathrm{~cm})$, and occurred due to the agricultural cultivation works and the deep loosening from the first two experimental cycles (1978 - 1986 and 1987 - 1996). The space between the tile drain lines resulted in the following horizon succession (Figure 4):

$\left(\mathrm{A}_{0}+\mathrm{E}_{\mathrm{a}}\right) \mathbf{p}$ - 0 - $30 \mathrm{~cm}$ : silt loam;

Ea+BW - 30 - $46 \mathrm{~cm}$ : clayey loam;

$\mathbf{B t}_{1} \mathbf{W}-46-97 \mathrm{~cm}$ : loam clay.

The analysed physical and chemical characteristics of soil sampled in 2010 were determined according to the norms of the Methodology of soil studies elaboration - National Institute of Research and Development in Soil Science, Agrochemistry and Environment Bucharest - 1987 and to the Romanian System of Soil Taxonomy - 2003.

\subsection{Hydrometeorological balance of field drainage pipes}

Depending on annual precipitation (P) and annual water consumption by evapotranspiration (ET) was expressed, on the basis of made observations during the experiment, the annual hydrometeorological balance $( \pm \Delta P=P-E T)$.

- Annual rainfall regime $(\mathrm{P})$ was the main source of excess water from the ground, being based on alternation between periods of intense rainfall and, respectively, dry periods in May. Database of observations made on annual rainfall were extracted for the case study examples, from a rainy year (1981), respectively, a dry year (1982).

For wet weather conditions area of north-eastern Romania, was considered as rainy year, 1981, with an annual rainfall of $968 \mathrm{~mm}$ fallen (statistical insurance 5\%) and the dry year, 1982, with annual rainfall of $742 \mathrm{~mm}$ insurance and $80 \%$ (Table 2). 
The average volume distribution of $855 \mathrm{~mm}$ from the years 1981-1982 was $541 \mathrm{~mm}(63 \%)$ in summer and $314 \mathrm{~mm}(27 \%)$ in winter.

\begin{tabular}{|c|c|c|c|}
\hline \multirow{2}{*}{ Year } & \multirow{2}{*}{$\begin{array}{c}\text { Annual rainfall } \\
(\mathrm{P} \mathrm{mm})\end{array}$} & \multicolumn{2}{|c|}{ Season rainfall distribution $(\mathrm{mm})$} \\
\cline { 3 - 4 } & & $\begin{array}{c}\text { Warm season } \\
\text { months (V-X) }\end{array}$ & $\begin{array}{c}\text { Cold season } \\
\text { months (XI-IV) }\end{array}$ \\
\hline 1981 & 968 & 592 & 376 \\
1982 & 742 & 489 & 253 \\
\hline Average & 855 & 541 & 314 \\
\hline
\end{tabular}

Table 2. Annual rainfall and seasonal distribution in 1981-1982.

- Average multi-annual rainfall throughout the period examined in the years 1978-2010 recorded an annual average value of $806 \mathrm{~mm}$ (50\% assurance).

In terms of annual rainfall distribution and intensity of growing seasons, months and calendar time intervals from one day up to 5 consecutive days of the years 1978-2010 have been reported following characteristics:

- $\quad$ In the hot season (V-X) the annual average year, rainfall was recorded $549 \mathrm{~mm}(68 \%)$, and in winter (XI-IV), $257 \mathrm{~mm}(32 \%)$.

- Average and maximum monthly rainfall recorded multi-annual, usually, recorded the largest amounts of water in June and July and lowest in January-March.

- Rainfall in periods of 1-5 consecutive days were characterized, throughout the study period, by the size and distribution on everyday, 2 days, 3 days and 5 days, depending on the overall progress of the climatic conditions (Table 3 ).

\begin{tabular}{|c|c|c|c|c|c|c|c|c|c|c|}
\hline \multirow{3}{*}{$\begin{array}{c}\text { Month of } \\
\text { the year }\end{array}$} & $\begin{array}{c}\text { Monthly } \\
\text { precipitation } \\
(\mathrm{mm})\end{array}$ & \multicolumn{3}{|c|}{ Rainfall in consecutive intervals of 1-5 days (mm) } \\
\cline { 2 - 10 } & average & max. & average & max. & average & max. & average & max. & average & max. \\
\hline & 33 & 69.3 & 12 & 25.7 & 16 & 31.3 & 18 & 36.5 & 20 & 49.2 \\
I & 34 & 80.2 & 11 & 18.9 & 14 & 23.2 & 16 & 30.0 & 18 & 33.5 \\
II & 33 & 63.0 & 11 & 25.1 & 12 & 25.1 & 14 & 25.1 & 16 & 28.3 \\
III & 80 & 12.3 & 26 & 41.3 & 33 & 53.6 & 38 & 65.5 & 45 & 79.9 \\
IV & 97 & 199.1 & 32 & 95.1 & 43 & 95.1 & 46 & 97.5 & 50 & 97.5 \\
V & 133 & 193.2 & 49 & 72.0 & 65 & 96.5 & 78 & 140.8 & 89 & 153.8 \\
VI & 133 & 236.5 & 40 & 89.1 & 51 & 100.7 & 54 & 109.6 & 62 & 137.0 \\
VII & 82 & 186.2 & 32 & 43.6 & 39 & 81.8 & 45 & 118.5 & 53 & 158.7 \\
VIII & 63 & 125.8 & 21 & 37.5 & 28 & 59.8 & 30 & 59.8 & 35 & 66.5 \\
IX & 41 & 127.5 & 16 & 39.5 & 21 & 73.4 & 21 & 75.8 & 24 & 98.2 \\
X & 41 & 105.1 & 18 & 38.5 & 23 & 59.4 & 24 & 61.4 & 26 & 62.2 \\
XI & 36 & 103.8 & 12 & 25.6 & 16 & 39.9 & 17 & 41.0 & 20 & 43.7 \\
XII & 806 & - & 280 & - & 361 & - & 401 & - & 458 & - \\
\hline Annual & 806 & -
\end{tabular}

Table 3. Multiannual precipitation (1978-2010), average and maximum, monthly and on intervals of 1-5 consecutive days. 
- Annual evapotranspiration regime (ET), ranged between the limits of normal distribution of the wet weather conditions. For the two characteristic years of the climate conditions (1981 and 1982), annual evapotranspiration was $559 \mathrm{~mm}$ (1981) and $580 \mathrm{~mm}$ (1982), with an average of $569 \mathrm{~mm}$. Distribution of mean annual evapotranspiration for the two growing seasons of the year difference between the value of $517 \mathrm{~mm}(91 \%)$ in the warm season, respectively, $52 \mathrm{~mm}(9 \%)$ in cold season of the year (Table 4$)$.

\begin{tabular}{|l|l|l|l|}
\hline \multirow{2}{*}{ Year } & \multirow{2}{*}{$\begin{array}{l}\text { Annual evapotranspiration } \\
(\text { Et mm })\end{array}$} & \multicolumn{3}{|l|}{ Seasonal distribution of evapotranspiration $(\mathrm{mm})$} \\
\cline { 3 - 4 } & & $\begin{array}{l}\text { Warm season } \\
\text { month (V-X) }\end{array}$ & $\begin{array}{l}\text { Cold season } \\
\text { month (XI-IV) }\end{array}$ \\
\hline 1981 & 559 & 505 & 54 \\
1982 & 580 & 529 & 51 \\
\hline Average & 569 & 517 & 52 \\
\hline
\end{tabular}

Table 4. Annual and seasonal evapotranspiration in years 1981 - 1982.

- Average annual evapotranspiration regime throughout the period examined in the years 1978-2010 recorded an average of $599 \mathrm{~mm}$ per year which varied in size according to the general trend of climatic factors and the use of agricultural land.

- Distribution of average annual evapotranspiration (1978-2010) on the two growing seasons, differentiate significantly separately. In the warm season (V-X), which corresponded to wet land with vegetation period of crops, has developed a water consumption of $481 \mathrm{~mm}$, which means $80 \%$ of annual average. In winter (XI-IV), evapotranspiration recorded in terms of annual average, water consumption of $118 \mathrm{~mm}$, which is $20 \%$.

- Average monthly evapotranspiration was characterized by maximum values during the months of summer season with a 90-142 mm consumption, small to medium in the months of spring - autumn, with a consumption of $1-76 \mathrm{~mm}$ and negligible values months of winter.

- Evapotranspiration and diurnal periods of up to 3-5 consecutive days, was typically, below the rainfalls in these intervals, which resulted in a surplus in the hydrometeorological water balance.

- The amount of excess water with other natural factors contributed to the formation and maintenance of the soil profile or on the land of excess rainfall from moisture.

- Annual hydrometeorological regime balance $( \pm \Delta \mathrm{P}=\mathrm{P}$ - Et $)$ registered in terms of the years 1981 to 1982 an average surplus of $286 \mathrm{~mm}, 162 \mathrm{~mm}$ annual distribution in 1982 and 409 $\mathrm{mm}$ in 1981 (Table 5).

\begin{tabular}{|c|c|c|c|c|c|c|c|c|c|c|c|c|}
\hline \multirow{3}{*}{ Year } & \multicolumn{4}{|c|}{$\begin{array}{c}\text { Annual hydro- } \\
\text { meteorological balance }\end{array}$} & \multicolumn{4}{|c|}{$\begin{array}{l}\text { Warm season } \\
\text { months }(\mathrm{V}-\mathrm{X})\end{array}$} & \multicolumn{4}{|c|}{$\begin{array}{l}\text { Cold season } \\
\text { months (XI-IV) }\end{array}$} \\
\hline & \multirow{2}{*}{$\begin{array}{c}\mathrm{P} \\
(\mathrm{mm})\end{array}$} & \multirow{2}{*}{$\begin{array}{c}\mathrm{Et} \\
(\mathrm{mm})\end{array}$} & \multicolumn{2}{|c|}{$\begin{array}{l} \pm \Delta \mathrm{P} \\
(\mathrm{mm})\end{array}$} & \multirow{2}{*}{$\begin{array}{c}\mathrm{P} \\
(\mathrm{mm})\end{array}$} & \multirow{2}{*}{$\begin{array}{c}\text { Et } \\
(\mathrm{mm})\end{array}$} & \multicolumn{2}{|c|}{$\begin{array}{l} \pm \Delta \mathrm{P} \\
(\mathrm{mm})\end{array}$} & \multirow{2}{*}{$\begin{array}{c}\mathrm{P} \\
(\mathrm{mm})\end{array}$} & \multirow{2}{*}{$\begin{array}{c}\mathrm{Et} \\
(\mathrm{mm})\end{array}$} & \multicolumn{2}{|c|}{$\begin{array}{l} \pm \Delta \mathrm{P} \\
(\mathrm{mm})\end{array}$} \\
\hline & & & + & - & & & + & - & & & + & - \\
\hline 1981 & 968 & 559 & 409 & - & 592 & 505 & 87 & - & 376 & 54 & 322 & - \\
\hline 1982 & 742 & 580 & 162 & - & 489 & 529 & - & 40 & 253 & 51 & 202 & - \\
\hline Average & 855 & 569 & 286 & - & 541 & 517 & 44 & 20 & 314 & 52 & 262 & - \\
\hline
\end{tabular}

Table 5. Annual hydro-meteorological balance and seasonal distribution in 1981-1982. 
Distribution of surplus and/or water deficit equation from annual hydrometeorological balance individualized only by excess water in 1981, respectively by excess and water deficit in 1982. The distribution of the two seasons average surplus of $286 \mathrm{~mm}$ to $262 \mathrm{~mm}$ difference between the value (92\%) in winter and $24 \mathrm{~mm}(8 \%)$ in summer.

- Hydrometeorological annual average regime balance of the period under review (1978-2010) recorded a surplus of $207 \mathrm{~mm}$ water, characterized by the following features on the seasons, months and characteristic times of the year.

- Distribution of the two growing seasons of the year differenced between $139 \mathrm{~mm}(67 \%)$, in the hot season of the year annual average and $68 \mathrm{~mm}(33 \%)$ in winter.

- Annual distribution of water surplus resulted from the hydrometeorological balance was characterized in terms of environment, positive in almost all months of the year.

- The average values of the determined period were employed between 0-11 mm minimum quantities, made in July, September and October and 31-40 mm maximum on the other months of the year, except August.

- In terms of climate, we can say that the August register, usually an average deficit of 11$20 \mathrm{~mm}$, offset by reserves of water stored in soil in winter. In this context, water scarcity may be an example of $40 \mathrm{~mm}$ was recorded in August of 1982, considered a dry year.

\subsection{Technical efficiency of the experimental drainage variants}

\subsubsection{Periods of drainage system operation}

In periods of drainage operation with non-permanent flow regime, rainfalls volume $(\mathrm{P})$ exceeded the water consumption by evapotranspiration (Et), deep infiltration (I) and drain the land surface $(\mathrm{S})$. In periods of excess water removal $(\Delta \mathrm{P})$, drained soil is working functionally as a reservoir, which records under the effect of heavy rains filling, respectively, depletion under the effect of drainage.

To characterize evolution of climatic factors that determine the hydro-meteorological balance and proper functioning of pipe drainage are presented the observations from the operation of drainage tubes in the years 1981-1982 (Table 6).

- Hydrometeorological balance, that helped triggering the operation of the drainage system with pipes, had on given weather conditions between 1981-1982, the following significant issues:

- Excess water $(\Delta \mathrm{P})$ derived from annual hydrometeorological balance recorded $625 \mathrm{~mm}$ in 1981 and $401 \mathrm{~mm}$ in 1982. This water surplus caused the total filling of the lacunar space of soil, which led to its discharge in the drainage tubes system.

- Dynamics of water surplus recorded in intervals of drainage operation was located, under review conditions, between the minimum values of $1-4 \mathrm{~mm}$ and maximum of $102-113 \mathrm{~mm}$.

- The functioning duration of drainage pipes of periods with water surplus totaled from 2 days to 20 consecutive days, as determined by the volume, duration and intensity of rainfalls.

\subsubsection{Specific drainage flows}

To characterize the dynamics of drainage specific flows, first were analyzed the observations from climatic conditions in 1981 and 1982. In periods of operation of drainage mentioned in 


\begin{tabular}{|c|c|c|c|c|c|}
\hline \multirow{2}{*}{ Year } & \multirow{2}{*}{ Drainage period } & \multirow{2}{*}{ Number of days } & \multicolumn{3}{|c|}{ Hydrometeorological balance } \\
\hline & & & $\mathrm{P}(\mathrm{mm})$ & Et $(\mathrm{mm})$ & $+\Delta \mathrm{P}(\mathrm{mm})$ \\
\hline \multirow{14}{*}{1981} & 3-17 II & 14 & 70 & 1 & 69 \\
\hline & 9-29 III & 20 & 100 & 10 & 90 \\
\hline & 27-30 IV & 3 & 22 & 7 & 15 \\
\hline & $6-18 \mathrm{~V}$ & 12 & 135 & 22 & 113 \\
\hline & $21-24 \mathrm{~V}$ & 3 & 18 & 6 & 12 \\
\hline & 10-19 VII & 9 & 90 & 38 & 52 \\
\hline & 21-25 VII & 4 & 22 & 18 & 4 \\
\hline & 27-31 VII & 4 & 53 & 16 & 37 \\
\hline & 1-4 VIII & 4 & 47 & 18 & 29 \\
\hline & 16-19 IX & 3 & 60 & 6 & 54 \\
\hline & $21-30$ XI & 9 & 105 & 3 & 102 \\
\hline & 7-15 XII & 8 & 20 & - & 20 \\
\hline & 16-31 XII & 15 & 28 & - & 28 \\
\hline & Annual & 108 & 770 & 145 & 625 \\
\hline \multirow{13}{*}{1982} & $12-31$ III & 20 & 122 & 10 & 112 \\
\hline & 1-5 IV & 4 & 3 & 2 & 1 \\
\hline & 19-24 IV & 5 & 20 & 5 & 15 \\
\hline & 28-30 IV & 2 & 40 & 3 & 37 \\
\hline & $1-5 \mathrm{~V}$ & 5 & 20 & 4 & 16 \\
\hline & $15-22 \mathrm{VI}$ & 7 & 108 & 25 & 83 \\
\hline & $25-29 \mathrm{VI}$ & 4 & 22 & 14 & 8 \\
\hline & 1-3 VII & 2 & 24 & 8 & 16 \\
\hline & 11-22 VII & 11 & 95 & 46 & 49 \\
\hline & 23-25 VII & 2 & 21 & 10 & 11 \\
\hline & 26-31 VII & 6 & 56 & 21 & 35 \\
\hline & 1-10 VIII & 9 & 50 & 32 & 18 \\
\hline & Annual & 77 & 581 & 180 & 401 \\
\hline
\end{tabular}

Table 6. Operating periods of drainage tubes in the years 1981 - 1982.

the previous paragraph, specific drainage flows (q) expressed in $1 / \mathrm{s}$ and ha for each drain line were characterized, generally, depending on specific factors.

Specific flow drainage dynamics was analyzed depending on the size of the excess rainwater and drainage lines efficiency, respectively, on the average assessed for the six experimental drainage variants (A, B, C, D, E and F). Also, tube drainage operation was highlighted both in terms of association with land shaping in the bedding system with ridges and furrows (variant $A$ ) and, respectively, aeration soil to a depth of 50-60 cm on average (variants B, C, D, E and F). In the early hours of operating periods of pipes drains were measured, typically, maximum flow, which measure on the evolution of precipitation increases and/or continuity of the excess volume of water till minimum values.

Specific flow regime of pipe drains drainage tubes was characterized on the base of volumetric flows measured 2-3 times daily, on the discharge place of each drain, in drainage operation during the years 1981 and 1982 (Table 7). 


\begin{tabular}{|c|c|c|c|c|c|c|c|c|c|c|}
\hline \multirow{3}{*}{$\begin{array}{c}\text { Variant } \\
\text { and } \\
\text { spacing } \\
\text { between } \\
\text { drain lines } \\
\text { /depth } \\
\text { drain (m) }\end{array}$} & \multirow{3}{*}{$\begin{array}{c}\text { Drain } \\
\text { line } \\
\text { number }\end{array}$} & \multicolumn{9}{|c|}{ Specific drainage flow $q\left(1 \cdot \mathrm{s}^{-1} \cdot \mathrm{ha}^{-1}\right)$} \\
\hline & & \multicolumn{3}{|c|}{$\begin{array}{l}\text { Maximum extreme } \\
\text { flows }\end{array}$} & \multicolumn{3}{|c|}{$\begin{array}{c}\text { Annual maximum } \\
\text { average flows }\end{array}$} & \multicolumn{3}{|c|}{$\begin{array}{c}\text { Annual average } \\
\text { flows }\end{array}$} \\
\hline & & 1981 & 1982 & Average & 1981 & 1982 & Average & 1981 & 1982 & Average \\
\hline \multirow{4}{*}{$\begin{array}{c}\text { A } \\
20 / 1.0\end{array}$} & 1 & 5.17 & 4.87 & 5.02 & 1.89 & 1.25 & 1.57 & 0.63 & 0.31 & 0.47 \\
\hline & 2 & 5.77 & 5.17 & 5.47 & 1.55 & 1.37 & 1.46 & 0.49 & 0.32 & 0.41 \\
\hline & 3 & 5.00 & 4.84 & 4.92 & 1.46 & 1.21 & 1.34 & 0.48 & 0.30 & 0.39 \\
\hline & Average & 5.31 & 4.96 & 5.14 & 1.63 & 1.28 & 1.46 & 0.53 & 0.31 & 0.42 \\
\hline \multirow{4}{*}{$\begin{array}{c}\text { B } \\
15 / 1.0\end{array}$} & 4 & 2.98 & 4.44 & 3.71 & 0.95 & 1.27 & 1.11 & 0.36 & 0.33 & 0.35 \\
\hline & 5 & 2.90 & 3.92 & 3.41 & 0.99 & 1.25 & 1.12 & 0.36 & 0.32 & 0.34 \\
\hline & 6 & 2.86 & 4.26 & 3.56 & 1.02 & 1.30 & 1.16 & 0.36 & 0.32 & 0.34 \\
\hline & Average & 2.91 & 4.21 & 3.56 & 0.99 & 1.27 & 1.13 & 0.36 & 0.32 & 0.34 \\
\hline \multirow{4}{*}{$\begin{array}{c}\mathrm{C} \\
12 / 1.0\end{array}$} & 7 & 3.85 & 6.25 & 5.05 & 1.30 & 1.80 & 1.55 & 0.48 & 0.41 & 0.45 \\
\hline & 8 & 3.97 & 5.95 & 4.96 & 1.39 & 1.74 & 1.57 & 0.48 & 0.42 & 0.45 \\
\hline & 9 & 4.17 & 6.58 & 5.38 & 1.38 & 1.66 & 1.52 & 0.48 & 0.46 & 0.47 \\
\hline & Average & 4.00 & 6.26 & 5.13 & 1.36 & 1.73 & 1.55 & 0.48 & 0.43 & 0.46 \\
\hline \multirow{4}{*}{$\begin{array}{c}D \\
20 / 0.8\end{array}$} & 10 & 2.50 & 4.17 & 3.34 & 0.87 & 1.24 & 1.06 & 0.31 & 0.29 & 0.30 \\
\hline & 11 & 3.13 & 3.49 & 3.31 & 0.95 & 1.15 & 1.05 & 0.33 & 0.28 & 0.31 \\
\hline & 12 & 2.94 & 3.20 & 3.07 & 0.96 & 1.01 & 0.99 & 0.33 & 0.27 & 0.30 \\
\hline & Average & 2.86 & 3.62 & 3.24 & 0.93 & 1.13 & 1.03 & 0.32 & 0.28 & 0.30 \\
\hline \multirow{4}{*}{$\begin{array}{c}E \\
15 / 0.8\end{array}$} & 13 & 4.00 & 5.41 & 4.71 & 1.23 & 1.69 & 1.46 & 0.44 & 0.41 & 0.43 \\
\hline & 14 & 3.33 & 5.71 & 4.52 & 1.22 & 1.51 & 1.37 & 0.42 & 0.40 & 0.41 \\
\hline & 15 & 4.00 & 5.13 & 4.57 & 1.32 & 1.59 & 1.46 & 0.45 & 0.37 & 0.41 \\
\hline & Average & 3.78 & 5.42 & 4.60 & 1.26 & 1.60 & 1.43 & 0.44 & 0.39 & 0.42 \\
\hline \multirow{4}{*}{$\begin{array}{c}\mathrm{F} \\
12 / 0.8\end{array}$} & 16 & 4.55 & 6.10 & 5.33 & 1.48 & 1.80 & 1.64 & 0.54 & 0.43 & 0.49 \\
\hline & 17 & 4.55 & 6.76 & 5.66 & 1.61 & 1.93 & 1.77 & 0.60 & 0.46 & 0.53 \\
\hline & 18 & 4.17 & 6.07 & 5.12 & 1.31 & 1.73 & 1.52 & 0.53 & 0.40 & 0.47 \\
\hline & Average & 4.42 & 6.31 & 5.37 & 1.47 & 1.82 & 1.64 & 0.56 & 0.43 & 0.50 \\
\hline
\end{tabular}

Table 7. The specific drainage flows in 1981-1982.

- $\quad$ The maximum extreme flows, measured in the first functioning hours of drainage under the conditions of the 18 drains lines showed obvious differences. In terms of the year 1981, measured flows were hierarchized between $2.50 \mathrm{l} \cdot \mathrm{s}^{-1}$ and ha (drain 10/variant D) and $5.77 \mathrm{l} \cdot \mathrm{s}^{-1}$ and ha (drain 2/variant A), and in 1982 from $3.20 \mathrm{l}^{-1} \mathrm{~s}^{-1}$ and ha (drain 12 /variant $\mathrm{D}$ ) and $6.761 . \mathrm{s}^{-1}$ and ha (drain 17 /variant $\mathrm{F}$ ).

- Annual maximum average flows were individualized on the 18 line pipe drains between the minimum value of $0.87 \mathrm{l} \cdot \mathrm{s}^{-1}$.ha (drain 10/variant D) and a maximum of $1.89 \mathrm{l} \cdot \mathrm{s}^{-}$ 1.ha (drain 1/variant A), during operation of drainage in 1981. There is a similar dynamic in terms of 1982, with a variation of this flow from $1.01 \mathrm{l}^{\mathrm{k}} \mathrm{s}^{-1}$.ha (drain 12/variant D) and up to $1.931 . \mathrm{s}^{-1} \cdot$ ha (drain 17 /variant $\mathrm{F}$ ).

- Annual average flows, that were expressed on the basis of all measurements from the 108 days in 1981 and 77 days in 1982 showed also, functional technical efficiency of solutions designed in the 18 lines of drainage. 
Mean annual specific drainage flows were correlated with the size of maximum flow and maximum annual extreme, both for individual conditions of drains, and also for the estimated average experimental version of drainage lines consisted of three drains lines. Thus, in 1981 the annual average flows ranged from $0.31 \cdot \mathrm{s}^{-1}$.ha (drain 10/variant D) and $0.63 \cdot \mathrm{s}^{-1}$.ha (drain 1 /variant A) and in 1982, from $0.27 \cdot \mathrm{s}^{-1} \cdot$ ha (drain $12 /$ variant $\mathrm{D}$ ) and 0.46 . $\mathrm{s}^{-1}$.ha (drain 17/variant F).

- Technical efficiency of drainage variants, depending on the size of the specific flows highlighted the following issues relevant to the experimental cycle:

- The size of discharged flows showed a higher efficiency of drains to the distance between them $12 \mathrm{~m}$ and average depth of $0.8 \mathrm{~m}$ and $1.0 \mathrm{~m}$ ( $\mathrm{F}$ and $\mathrm{C}$ variants), who drained a $20 \%$ to $70 \%$ more, compared to variants with distance between drains of $15 \mathrm{~m}$ and $20 \mathrm{~m}$.

- Association of the pipe drainage with the soil shaping combined with the bedding system at the same distance of $20 \mathrm{~m}$ (variant A) provided a capture and efficient evacuation of excess water, comparable to the distance between drains variant $\mathrm{F} 12 \mathrm{~m}$ and average depth of $0.8 \mathrm{~m}$.

- The usage of a filter layer as a prism with dimensions of $20 \times 70 \mathrm{~cm}$ was achieved from Ballast and flax strains on drained 1/A, and from ballast on drain 2/A, ballast layer with a thickness of $20 \mathrm{~cm}$, on drained 3/A did not show a high functional efficiency.

- The increase of the distance between the drains or drain depth settlement resulted in a reduction of debts discharged, except association of pipe drainage tubes with land shaping in the bedding system with ridges and furrows (variant $\mathrm{A}$ ).

\subsubsection{Drained water volumes}

Depending on the size of specific drainage daily flow of the area served by the drainage lines (1-18) and experimental drainage variants (A-F) volumes of drained water were calculated, expressed in $\mathrm{mm}$ or $\mathrm{m}^{3} \cdot \mathrm{ha}^{-1}$. To calculate the volume of drained water areas were used areas of 0.60 ha (variants A and D), 0.45 ha (variants B and E), and 0.36 ha (variants C and F).

- Average annual volumes of drained water (Table 8), in the excess water conditions during 1981 and 1982 showed a differentiated technical efficiency, first drain lines respectively arranged on the six variants, as follows:

- The individual efficiency of the component drains of the network drainage was illustrated by the size of drained water volumes, which ranged from $232 \mathrm{~mm}(2320$ $\left.\mathrm{m}^{3} / \mathrm{ha}\right)$ for drain 12 / D and maximum of $406 \mathrm{~mm}\left(4060 \mathrm{~m}^{3} / \mathrm{ha}\right)$ for drain 1 / A, associated with land shaping in the bedding system with ridges and furrows.

- Operational efficiency of the experimental variants, depending on the size of individual volumes of component drains was noted by a reduced capacity for variant $\mathrm{D}(20 / 0.8 \mathrm{~m})$ with a drain rate of $245 \mathrm{~mm}\left(2450 \mathrm{~m}^{3} \cdot \mathrm{ha}^{-1}\right)$ and better under variant $\mathrm{F}(12 / 0.8 \mathrm{~m})$, which achieved a $368 \mathrm{~mm}$ drained rate $\left(3680 \mathrm{~m}^{3} \cdot \mathrm{ha}^{-1}\right)$.

- Technical efficiency of drainage variants, depending on the size of the drained water volumes was materialized through the following significant features:

- Operating mode of the drains lines is dependent on seasonal rainfall distribution and consumption of water by evapotranspiration. 


\begin{tabular}{|c|c|c|c|c|c|c|c|c|c|c|}
\hline \multirow{3}{*}{$\begin{array}{l}\text { Spacing } \\
\text { between } \\
\text { drain lines } \\
\text { /depth } \\
\text { drain (m) }\end{array}$} & \multirow{3}{*}{$\begin{array}{l}\text { Drain } \\
\text { line } \\
\text { number }\end{array}$} & \multirow{2}{*}{\multicolumn{3}{|c|}{$\begin{array}{l}\text { The annual volume of } \\
\text { drained water (mm) }\end{array}$}} & \multicolumn{6}{|c|}{$\begin{array}{l}\text { Seasonal distribution of drained water } \\
\text { volumes }(\mathrm{mm})\end{array}$} \\
\hline & & & & & \multicolumn{3}{|c|}{ Warm season $(\mathrm{V}-\mathrm{X})$} & \multicolumn{3}{|c|}{ Cold season (XI-IV) } \\
\hline & & 1981 & 1982 & Average & 1981 & 1982 & Average & 1981 & 1982 & Average \\
\hline \multirow{4}{*}{$\begin{array}{c}\text { A } \\
20 / 1,0\end{array}$} & 1 & 583 & 229 & 406 & 202 & 102 & 152 & 381 & 127 & 254 \\
\hline & 2 & 469 & 211 & 340 & 185 & 110 & 147 & 284 & 101 & 192 \\
\hline & 3 & 395 & 178 & 287 & 166 & 82 & 124 & 229 & 96 & 163 \\
\hline & Average & 482 & 206 & 344 & 184 & 98 & 141 & 298 & 108 & 203 \\
\hline \multirow{4}{*}{$\begin{array}{c}\text { B } \\
15 / 1,0\end{array}$} & 4 & 359 & 207 & 283 & 143 & 114 & 128 & 216 & 93 & 155 \\
\hline & 5 & 360 & 205 & 283 & 142 & 111 & 126 & 218 & 94 & 156 \\
\hline & 6 & 352 & 192 & 272 & 144 & 98 & 121 & 208 & 94 & 151 \\
\hline & Average & 357 & 201 & 279 & 143 & 107 & 125 & 214 & 94 & 154 \\
\hline \multirow{4}{*}{$\begin{array}{c}\mathrm{C} \\
12 / 1,0\end{array}$} & 7 & 456 & 273 & 364 & 177 & 142 & 159 & 279 & 131 & 205 \\
\hline & 8 & 453 & 273 & 363 & 175 & 139 & 157 & 278 & 134 & 206 \\
\hline & 9 & 433 & 248 & 341 & 164 & 117 & 140 & 269 & 131 & 200 \\
\hline & Average & 447 & 265 & 356 & 172 & 133 & 152 & 275 & 132 & 204 \\
\hline \multirow{4}{*}{$\begin{array}{c}\mathrm{D} \\
20 / 0,8\end{array}$} & 10 & 310 & 189 & 249 & 125 & 100 & 112 & 185 & 89 & 137 \\
\hline & 11 & 327 & 183 & 255 & 128 & 100 & 114 & 199 & 83 & 141 \\
\hline & 12 & 324 & 139 & 232 & 134 & 69 & 101 & 190 & 70 & 130 \\
\hline & Average & 320 & 170 & 245 & 129 & 90 & 109 & 191 & 80 & 136 \\
\hline \multirow{4}{*}{$\begin{array}{c}E \\
15 / 0,8\end{array}$} & 13 & 432 & 258 & 345 & 171 & 137 & 154 & 261 & 121 & 191 \\
\hline & 14 & 440 & 240 & 340 & 177 & 118 & 148 & 263 & 122 & 193 \\
\hline & 15 & 430 & 239 & 335 & 169 & 122 & 145 & 261 & 117 & 189 \\
\hline & Average & 434 & 246 & 340 & 172 & 126 & 149 & 262 & 120 & 191 \\
\hline \multirow{4}{*}{$\begin{array}{c}\mathrm{F} \\
12 / 0,8\end{array}$} & 16 & 457 & 279 & 368 & 182 & 148 & 165 & 275 & 131 & 203 \\
\hline & 17 & 482 & 296 & 389 & 196 & 155 & 176 & 286 & 141 & 214 \\
\hline & 18 & 428 & 265 & 347 & 171 & 136 & 154 & 257 & 129 & 193 \\
\hline & Average & 456 & 280 & 368 & 183 & 146 & 165 & 273 & 134 & 203 \\
\hline
\end{tabular}

Table 8. Drained water volumes regime in 1981-1982.

- Maintenance of the same spacing between the drain lines of $12 \mathrm{~m}$ or $15 \mathrm{~m}$ and increase of the depth of drains from $0.8 \mathrm{~m}$ to $1.0 \mathrm{~m}$ contribute in reducing the excess capacity of water interception by an average of $3 \%$ for a distance of $12 \mathrm{~m}$ (variant $\mathrm{F}$ to variant $\mathrm{C}$ ) and $22 \%$ for distance of $15 \mathrm{~m}$ (variant $\mathrm{E}$ to variant $\mathrm{B}$ ).

- Drained soil aeration to an average depth of 50-60 $\mathrm{cm}$ resulted in an improvement in rainfall interception excess water by about $2-9 \%$, according to the first two lines of drains (B, C, D, E, F variants) than the unaerated surface soil of the third drain.

- Average volumes of drained water from the corresponding size of the excess moisture from rainfall from 1981 and 1982, on the 6 variant were distributed among the $48 \%$ efficiency (variant D) and up to $72 \%$ (variant F).

- $\quad$ Drained water volumes were found in large quantities during the cold season (XI -IV) and lower in the warm season of the year $(\mathrm{V}-\mathrm{X})$.

- The exploitation behaviour of the drainage lines of the experimental variants, showed an increase in water drained in variants when the distance between drains variants was $12 \mathrm{~m}$ and average depth of $0.8 \mathrm{~m}$ or $1.0 \mathrm{~m}$. 


\subsubsection{The capture capacity of drain pipes}

The excess stagnant water from the surface of the field and/or as pedophreatic water in the upper part of the soil structure must be evacuated in a relatively optimal period of time.

Before the descendent water current from the soil structure gets into the drain pipe it encounters a series of resistances that in general depend of the following natural factors and arrangement conditions:

- the permeability of the soil arranged with pipe drainage works;

- the permeability of the soil in the cross-sections of drain lines;

- $\quad$ the type and thickness of complex drain + filter;

- $\quad$ the pipe type and diameter;

- the distribution and the surface of the joints / perforations that allow the water to enter into the drain pipes.

According to van Someren (1964), the total energy losses in pipes $(\Delta \mathrm{h})$ that are due to the resistances that appear when the water enters the drain pipe and that is measured at the middle of the distance between the drains, can be divided into the following three categories.

- Horizontal energy losses $\left(\Delta h_{0}\right)$ that are to the resistances encountered by the water current at the passage through the soil, up to approximately $1.0 \mathrm{~m}$ away from the drain pipe.

- Radial energy losses $\left(\Delta h_{r}\right)$ that is due to the convergence of the water current lines, from the immediate area of the drain pipe.

- Entrance energy losses $\left(\Delta h_{i}\right)$ that are determined by the resistances encountered by the water current when entering into the drain pipe.

For the water current to enter into the drain pipe, the total energy losses $(\Delta h)$ from the middle of the spacing between the drain lines must be higher than the sum of the partial energy losses:

$$
\Delta \mathrm{h}>\Delta \mathrm{h}_{0}+\Delta \mathrm{h}_{\mathrm{r}}+\Delta \mathrm{h}_{\mathrm{i}}
$$

The studies made on the total energy losses $(\Delta h)$, under the conditions of a non-permanent regime were analyzed in the hypothesis of knowing the period of time ( $t$ days) in which the water level must be lowered from the maximum height $\left(h_{0}\right)$ to the minimum height $\left(h_{t}\right)$.

The effect of the total energy losses $\left(\Delta h=h_{0}-h_{t}\right)$ was followed in the piezometric pipe situated at the middle of the spacing between the drain pipes, with the distance between them of $12 \mathrm{~m}$ and the medium depth of $0.8 \mathrm{~m}$. At different periods of time ( $\mathrm{t}$ ), the total energy loss was represented, in general, by the decrease of the excess water level at the maximum height of the depression curve of $60-70 \mathrm{~cm}$, the best height of $15-20 \mathrm{~cm}$. At the same periods of time $(t)$ the drained flows decreased from $9-101 /$ minute to $0.11 /$ minute.

- the factor of the draining intensity $\left(a=\frac{1}{\mathrm{~J}}\right)$ was determined in the base of the measured levels in the piezometer from the middle of the spacing between the drain lines, at the beginning and the end of the draining's functioning periods, with the help of the following relation: 


$$
a=\frac{1}{\mathrm{~J}}=\frac{2.3\left(\log h_{o}-\log h_{t}\right)}{t}
$$

where:

$a$ - factor of the draining intensity (days $\left.{ }^{-1}\right)$

$h_{0}$ - maximum height of the pedophreatic water level

$h_{t}$ - minimum height of the pedophreatic water level

$\mathrm{t}$ - period of time (days).

Depending of the amount of rain that fell, that in periods of 3 - 5 consecutive days, registered values of up to $60-140 \mathrm{~mm}$, there were differentiated as well the values of the intensity draining factors. So, depending of the total energy losses $(\Delta \mathrm{h})$, after the previously mentioned rains, the values of the draining intensity were of $4-6$ days, during the hot season, and of 6 - 14 days, during the cold season (Table 9).

\begin{tabular}{|c|c|c|c|c|c|}
\hline Time $(\mathrm{t})$ & $\begin{array}{c}\text { The height of the depression curve } \\
\text { at the middle of the spacing } \\
\text { between the drain pipes }\end{array}$ & $\begin{array}{c}\text { Total energy } \\
\text { losses }\end{array}$ & $\begin{array}{c}\text { Factor } \\
a=\frac{1}{\mathrm{~J}}\end{array}$ & $\begin{array}{c}\text { Coefficient } \\
\mathrm{J}=\frac{1}{\mathrm{a}}\end{array}$ \\
\hline days & $\mathrm{h}_{0}(\mathrm{~mm})$ & $\mathrm{h}_{\mathrm{t}}(\mathrm{mm})$ & $\Delta \mathrm{h}(\mathrm{mm})$ & days -1 & - \\
\hline 5 & 690 & 300 & 390 & 0.167 & 6.0 \\
7 & 660 & 200 & 460 & 0.171 & 5.8 \\
5 & 620 & 290 & 330 & 0.152 & 6.6 \\
4 & 620 & 270 & 350 & 0.208 & 4.8 \\
5 & 620 & 190 & 430 & 0.236 & 4.2 \\
11 & 520 & 240 & 280 & 0.070 & 14.3 \\
2 & 380 & 250 & 130 & 0.209 & 4.8 \\
4 & 320 & 200 & 120 & 0.117 & 8.5 \\
\hline
\end{tabular}

Table 9. The draining intensity factor depending of the total energy loss.

- the filtration coefficient $(K)$ was characterized by a very good permeability, in the arable layer of $0-25 \mathrm{~cm}\left(K=3.2 \mathrm{~m} \cdot\right.$ day $\left.^{-1}\right)$, fact that assured the high degree of efficiency of the process of draining the excess water. In the case of the underlying horizon that was analyzed for the depth of $25-65 \mathrm{~cm}$, the permeability was lower $\left(\mathrm{k}=0.2 \mathrm{~m} \cdot \mathrm{day}^{-1}\right)$, fact that determined the execution and the periodical renewal of the soil loosening process until the necessary depth of $70-80 \mathrm{~cm}$.

- the draining porosity was correlated with the values that resulted in the case of the filtration coefficient, being characterized by medium to high values of $44-54 \%$ of the arable layer $(0-25 \mathrm{~cm}$ ) and by small values of $2-6 \%$ in the underlying layer of $25-65$ $\mathrm{cm}$.

Pores larger than 10-30 $\mu$ form the drainage porosity, usually occupied by air, but through which is drained by way of infiltration the water excess. The $30 \mu$ diameter is found in sandy soils and the $10 \mu$ in the medium and coarse textured soils. Utile porosity includes mediumsized pores with a diameter between 0.2 and 10 to $30 \mu$, which are able to retain either air or mobile water accessible to plants. Inactive porosity includes smaller pores, with diameters under $0.2 \mu$, which retain the water inaccessible to plants (Canarache, 1990). Drained porosity, utile porosity and inactive porosity are the basic components of total porosity. The 
variation of these three components characterizes the soil compaction condition according to the determining factors. For organic and organo-mineral soils, favourable conditions exist when the drained porosity is greater than 20\%; however, this requires installation of a drainage system (Canarache, 1991).

\subsubsection{The behaviour during the use of draining pipes}

In the case of the soils with excessive rain water, the functioning system of the drain pipes is determined by the size and the aleatory distribution of the rain water quantity. In a series of successive periods of time water excess appears in the soil and/or on the surface of the soil, excess that must be evacuated through a drainage system.

The evaluation of the water survey in the conditions of the existent 18 draining lines $(1,2,3$, ..., 18) and respectively, of the six experimental drainage variants (A, B, C, D, E and F) was analyzed taking into consideration the long time observations that were realized on the following factors:

- $\quad$ the daily precipitations;

- $\quad$ the average daily temperature of the air;

- the real maximum daily evapotranspiration;

- the daily water flow evacuated by drain pipes;

- the water volumes evacuated by drainage network.

The annual dynamic of the climatic factors from the period 1978 - 2010 that was also presented in the previous paragraphs respected the characteristics of the areas from the wet climate area of Romania, area that includes the Baia Depression as well.

The synthesis of the results obtained during the entire period of time when pipes drain experiments were made, can be characterized according to the annual and the seasonal dynamic of the climatic factors and the functional efficiency of the drainage system, as follows:

- $\quad$ The multiannual precipitation regime - it was characterized by a medium quantity of 806 $\mathrm{mm}$, with an annual distribution between the maximum quantity of $968 \mathrm{~mm}$ (1981), with a $5 \%$ assurance, and the minimum quantity of $455 \mathrm{~mm}$ (1986), with a $95 \%$ assurance.

- The real maximum evapotranspiration, having a medium multiannual value of $599 \mathrm{~mm}$ situated between the limits of the normal distribution from the wet areas.

- Effective water surplus that resulted from the equation of the water survey from the drained soil, from the periods of time the drainage system with pipes worked registered a medium multiannual value of $325 \mathrm{~mm}$ or $3250 \mathrm{~m}^{3} \cdot \mathrm{ha}^{-1}$ (Table 10).

- The medium volumes of drained water differentiated, in general, according to the dimensional elements and the nature of the construction materials used at the draining system. In the conditions of the equipping the 18 draining lines, the maximum norm of drained water $2070 \mathrm{~m}^{3} \cdot \mathrm{ha}^{-1}$ (64\% of the medium water excess) was reached at the drain 17 /variant $F$. The minimum norm of $1110 \mathrm{~m}^{3} \cdot \mathrm{ha}^{-1}$ was found at drain 12 /variant $\mathrm{D}$ with the distance between the drains of $20 \mathrm{~m}$ and the medium depth of the pipes of $0.80 \mathrm{~m}$ (Table 10). 
- The medium daily water flow was individualized between the maximum values of up to $3.5 \mathrm{~mm} \cdot$ day $^{-1}$ (drain 17/variant F) and the minimum values of $1.8 \mathrm{~mm}$ day $^{-1}$ (drain 12 /variant D), according to the materials that were used and the dimensional elements of the drainage system (Table 10).

\begin{tabular}{|c|c|c|c|c|c|c|c|}
\hline \multirow{3}{*}{$\begin{array}{l}\text { Variant } \\
\text { and } \\
\text { spacing } \\
\text { between } \\
\text { drain lines } \\
\text { / depth } \\
\text { drain (m) }\end{array}$} & \multirow{3}{*}{$\begin{array}{l}\text { Drain } \\
\text { line } \\
\text { number }\end{array}$} & \multirow{3}{*}{$\begin{array}{c}\text { Pipe type } \\
\text { and diameter }(\mathrm{mm})\end{array}$} & \multirow{3}{*}{$\begin{array}{c}\text { Surface of } \\
\text { the pipes } \\
\text { joints / } \\
\text { perforation } \\
\quad \mathrm{s} \\
\left(\mathrm{cm}^{2} \cdot \mathrm{m}^{-1}\right)\end{array}$} & \multicolumn{4}{|c|}{ Drained soil water balance } \\
\hline & & & & \multirow{2}{*}{$\begin{array}{c}\text { Mean } \\
\text { water } \\
\text { excess } \\
\left(\mathrm{m}^{3} \cdot \mathrm{ha}^{-1}\right)\end{array}$} & \multicolumn{2}{|c|}{$\begin{array}{l}\text { Mean } \\
\text { drained } \\
\text { water }\end{array}$} & \multirow{2}{*}{$\begin{array}{c}\text { Mean } \\
\text { daily } \\
\text { water flow } \\
\left(\mathrm{mm} \cdot \text { day }^{-1}\right)\end{array}$} \\
\hline & & & & & $\mathrm{m}^{3} \cdot \mathrm{ha}^{-1}$ & $\%$ & \\
\hline \multirow{4}{*}{$\begin{array}{c}\text { A } \\
20 / 1,0\end{array}$} & 1 & Tile $\varnothing 70$ & $10-15$ & \multirow{3}{*}{3250} & 1830 & 56 & 3.0 \\
\hline & 2 & Tile $\varnothing 125$ & $13-20$ & & 1610 & 50 & 2.7 \\
\hline & 3 & Tile $\varnothing 70$ & $10-15$ & & 1390 & 43 & 2.3 \\
\hline & \multicolumn{2}{|r|}{ Average } & - & - & 1610 & 50 & 2.7 \\
\hline \multirow{4}{*}{$\begin{array}{c}\text { B } \\
15 / 1,0\end{array}$} & 4 & Tile $\varnothing 70$ & $10-15$ & \multirow{3}{*}{3250} & 1370 & 42 & 2.3 \\
\hline & 5 & Tile $\varnothing 70$ & $10-15$ & & 1460 & 45 & 2.4 \\
\hline & 6 & Tile $\varnothing 70$ & $10-15$ & & 1440 & 44 & 2.4 \\
\hline & \multicolumn{2}{|r|}{ Average } & - & - & 1423 & 44 & 2.4 \\
\hline \multirow[t]{2}{*}{$\begin{array}{c}\mathrm{C} \\
12 / 1,0\end{array}$} & $\begin{array}{l}7 \\
8 \\
9\end{array}$ & $\begin{array}{c}\text { Corrugated plastic } \varnothing \\
65 \\
\text { Smooth plastic } \varnothing 63 \\
\text { Tile } \varnothing 70\end{array}$ & $\begin{array}{l}15-30 \\
15-30 \\
10-15\end{array}$ & 3250 & $\begin{array}{l}1870 \\
1850 \\
1770\end{array}$ & $\begin{array}{l}58 \\
57 \\
55\end{array}$ & $\begin{array}{l}3.1 \\
3.1 \\
2.9\end{array}$ \\
\hline & \multicolumn{2}{|r|}{ Average } & - & - & 1830 & 57 & 3.0 \\
\hline \multirow[t]{2}{*}{$\begin{array}{c}\mathrm{D} \\
20 / 0,8\end{array}$} & $\begin{array}{l}10 \\
11 \\
12\end{array}$ & $\begin{array}{c}\text { Corrugated plastic } \varnothing \\
65 \\
\text { Smooth plastic } \varnothing 110 \\
\text { Tile } \varnothing 70\end{array}$ & $\begin{array}{l}15-30 \\
30-40 \\
10-15\end{array}$ & 3250 & $\begin{array}{l}1260 \\
1360 \\
1110\end{array}$ & $\begin{array}{l}39 \\
42 \\
34\end{array}$ & $\begin{array}{l}2.1 \\
2.3 \\
1.8\end{array}$ \\
\hline & \multicolumn{2}{|r|}{ Average } & - & - & 1243 & 38 & 2.1 \\
\hline \multirow{4}{*}{$\begin{array}{c}\mathrm{E} \\
15 / 0,8\end{array}$} & 13 & Tile $\varnothing 70$ & $10-15$ & \multirow{3}{*}{3250} & 1800 & 55 & 3.0 \\
\hline & 14 & Tile $\varnothing 70$ & $10-15$ & & 1840 & 57 & 3.1 \\
\hline & 15 & Tile $\varnothing 70$ & $10-15$ & & 1790 & 55 & 3.0 \\
\hline & \multicolumn{2}{|r|}{ Average } & - & - & 1810 & 56 & 3.0 \\
\hline \multirow[t]{2}{*}{$\begin{array}{c}F \\
12 / 0,8\end{array}$} & $\begin{array}{l}16 \\
17 \\
18\end{array}$ & $\begin{array}{c}\text { Corrugated plastic } \varnothing \\
65 \\
\text { Smooth plastic } \varnothing 63 \\
\text { Tile } \varnothing 70\end{array}$ & $\begin{array}{l}15-30 \\
15-30 \\
10-15\end{array}$ & 3250 & $\begin{array}{l}1900 \\
2070 \\
1750\end{array}$ & $\begin{array}{l}58 \\
64 \\
54\end{array}$ & $\begin{array}{l}3.2 \\
3.5 \\
2.9\end{array}$ \\
\hline & & Average & - & - & 1907 & 59 & 3.2 \\
\hline
\end{tabular}

Table 10. The regime of the volumes of drained water in the period 1978 - 2010.

From the analysis of the functional efficiency of the experimented draining variants that were analyzed during the entire period of exploitation, results the following: 
- The growth of the drains depth from 0.8 to $1.0 \mathrm{~m}$ and keeping the spacing between the drain lines to a constant level of $12 \mathrm{~m}$ contributed at the decrease of the functional efficiency of the drainage system, with an average of $11 \%$.

- The growth of the spacing between the drain lines from 12 to $20 \mathrm{~m}$ and keeping of the drains depth at $0.80 \mathrm{~m}$ determined a decrease of the functional efficiency, with an average of $16 \%$.

- The surface of the drain pipes joints / perforations determined the growth of the functional efficiency, with an average of $11-12 \%$ (drain 17), in relation to drain 18 when the spacing between the drains was of $12 \mathrm{~m}$ and the medium depth was of $0.80 \mathrm{~m}$ (variant F).

- The association of the pipe drainage system with the land shaping in the bedding system with ridges and furrows, with an average of $23 \%$ (variant $\mathrm{A}$ ).

\subsection{Classification and qualitative evaluation of soil}

Soil-field mapping units, considered ecologically homogeneous, were established between the limits of the six experimental (Figure 1) plots arranged for subsurface drainage, having the following useful areas: 0.60 ha (A and D); 0.45 ha (B and E); 0.36 ha (C and F).

The calculation of classification notes for crops was done according to the 17 eco-soil indicators of natural conditions for unimproved soil and, respectively, of the conditions for drained, improved and cultivated soil. According to the classification marks, established for each plot of the two plots, we gave the average mark per uses and crops of the control plot and of the drainage plot.

In the case of quality classes, the classification marks were grouped from 20 to 20 marks: I (81-100 points); II (61-80 points); III (41-60 points); IV (21-40 points); V (0-20 points).

- Classification and qualitative evaluation of unimproved soil

Under soil genetic conditions of the microclimate from the Baia Depression, with a lower mean annual temperature $\left(7.9^{\circ} \mathrm{C}\right)$, early frost and late thawing, at which higher mean annual rainfall are added $(806 \mathrm{~mm})$, frequently stagnant water excess takes place on the field surface, at different periods of the year.

Among the important limitative factors of the production that were found in the natural conditions of albic stagnic-glossic Luvosol, used as "hygrophilous natural meadow", we noticed the following: stagnant moisture excess, soil acidity, soil compaction, low humus content.

Soil texture is dusty-loam at the depth $0-20 \mathrm{~cm}$, and then it becomes average loam-clayey, in the subjacent layer $20-40 \mathrm{~cm}$ and clayey-loam deep in the soil.

Total porosity was generally correlated to the clay content $(<0.002 \mathrm{~mm})$, being characterized by equal values of $52-65 \%$ at the depth $0-20 \mathrm{~cm}$ and respectively, $44-47 \%$ at the depth $20-40$ $\mathrm{cm}$.

Soil response is moderately acid at depth $0-40 \mathrm{~cm}$.

Base saturation degree $\left(\mathrm{V}_{\mathrm{Ah}}\right)$ is found within the oligomesobasic limits of 40-70\%. 
The humus content has recorded relatively high values until 194-199 $\mathrm{t} \cdot \mathrm{ha}^{-1}$ in the layers 0-5 and 5-18 cm. In the next two horizons EaW $(18-30 \mathrm{~cm})$ and EBW $(36-40 \mathrm{~cm})$, the humus reserve decreases once with depth until very low values.

The classification of farm field for the above-mentioned soil genetic conditions and actual use of "hygrophilous natural meadow" led to average classification marks of 39 points (Table $11)$.

\begin{tabular}{|c|c|c|c|c|}
\hline Soil unit & $\begin{array}{l}\text { Soil unit } \\
\text { area (ha) }\end{array}$ & Agricultural use and crops & $\begin{array}{c}\text { Classification } \\
\text { note }\end{array}$ & $\begin{array}{c}\text { Quality } \\
\text { class }\end{array}$ \\
\hline \multirow{10}{*}{$\begin{array}{l}\text { Unimproved } \\
\text { albic stagnic- } \\
\text { glosic } \\
\text { Luvosol }\end{array}$} & \multirow{10}{*}{3.0} & Pastures & 42 & III \\
\hline & & Hayfield & 35 & IV \\
\hline & & Average field meadows & 39 & IV \\
\hline & & Wheat & 10 & $\mathrm{~V}$ \\
\hline & & Barley & 9 & V \\
\hline & & Maize & 9 & $\mathrm{~V}$ \\
\hline & & Potato & 10 & V \\
\hline & & Flax & 14 & $\mathrm{~V}$ \\
\hline & & Alfalfa & 26 & IV \\
\hline & & Average arable land & 13 & $\mathrm{~V}$ \\
\hline
\end{tabular}

Table 11. Field classification for the natural conditions of the control plot- Baia Depression.

In the case of using albic stagnic-glossic Luvosol as arable land, we have evaluated the suitability of the first six crops in the wet climatic area. The average classification marks comprised between 9 points (barley and maize) and 26 points (alfalfa) led to an average of the control plot of 13 points.

The natural soil classification has shown the following defaults: water stagnation at field surface, soil stagnogleyzation, soil-ground water depth and soil acidity and compaction.

- Classification and qualitative evaluation of improved soil

By planning the subsurface drainage and applying agro-soil ameliorative works, we noticed a significant improvement of the general physical and chemical condition of the drained soil.

Soil texture was dusty-loam at the depth of 0-20 cm, while at the depth of $20-40 \mathrm{~cm}$ it was dusty clayey-loam, because of the mixture between genetic horizons, after soil loosening and cultivation works.

Total porosity with values between 50 and $55 \%$, at depths $0-40 \mathrm{~cm}$, has shown a weak soil loosening after the three exploitation cycles.

Soil acidity was maintained within the limits corresponding to moderately acid to weakly acid soils, because of the long-term effect of limestone applied in 1978 and 1988.

Base saturation degree $\left(\mathrm{V}_{\mathrm{Ah}}\right)$ was maintained in the first two cycles (1978 - 1986 and 1986 1997) between the limits of 71-90\%, moderately mesobasic. In 2010, the base saturation degree of $48-53 \%$, corresponding to the extremely oligomesobasic field, required limestone amendment. 
Humus content that was determined after the 32-year exploitation periods, pointed out the effect of intense mineralization of humic substances.

By the application of controlling moisture excess works, the "increase" of classification marks of natural conditions was done.

Thus, we mention the diminution of defaults determined by classification coefficients for average annual rainfall, stagnant moisture excess and soil stagnogleyzation.

Agro-soil ameliorative works have also contributed to the "increase" of classification marks for the favourable correction of soil response, total porosity and organic matter content from soil. For the increased conditions of using soil for "pastures and hayfields" there were good average classification marks of 79-88 points, with an average of the drainage plot of 84 points that framed the improved farm field in the first quality class, with a very good fertility (table 12).

\begin{tabular}{|c|c|c|c|c|}
\hline Soil unit (SU) & $\begin{array}{c}\text { SU area } \\
\text { (ha) }\end{array}$ & Agricultural use and crops & $\begin{array}{c}\text { Classification } \\
\text { note }\end{array}$ & $\begin{array}{c}\text { Quality } \\
\text { class }\end{array}$ \\
\hline \multirow{5}{*}{} & & Pastures & 88 & I \\
& & Hayfield & 79 & II \\
\cline { 3 - 5 } & & Average field meadows & 84 & I \\
\cline { 3 - 5 } Improved albic & \multirow{2}{*}{2.82} & Wheat & 57 & III \\
stagnic-glossic Luvosol & & Barley & 50 & III \\
& & Maize & 56 & III \\
& & Potato & 61 & II \\
& & Flax & 79 & II \\
& & Alfalfa & 81 & I \\
\cline { 3 - 5 } & & Average arable land & 64 & II \\
\hline
\end{tabular}

Table 12. Field classification for the increased conditions of the drainage field-Baia Depression.

The use of the improved soil as "arable field" framed the drained field between the average classification marks of 50 points for barley and until 81 points for alfalfa. The average of the classification marks of the drainage group for the first six crops of 64 points framed the use as "arable field" in the second quality class with a good fertility.

\section{Conclusion}

Sustainable development of the agricultural area of Romania requires a balance between economic growth and environmental protection, depending on soil quality and the strategy of exploitation for land fund.

Comprehensive soil studies in Suceava County, on an area of 398,771 ha has allowed for classification of soil in ten classes and nineteen types of soil. Among the limiting factors of agricultural growth in the natural sol-units, one can mention: excess moisture, erosion by water, acidity, flood hazard, soil compaction and low permeability soils.

Excess moisture of pluvial nature and/or from groundwater, plus the overflowing of hydrographic networks, showed up in various forms and intensities on a surface of 185,316 ha, which represents $21.7 \%$ of the total area of Suceava County. 
The diversity of natural conditions and the intrinsic characteristics of soil resources have determined a condition of middle to poor quality and suitability of the soil-units for agricultural use. In accordance with the specific requirements for soil crust improvements, in time were laid out a succession of hydro-ameliorative works.

Among these types of works, there can be emphasized the systems with ditches on a surface of about 55,000 ha and the pipes drainage on approximately 27,000 hectares, comprised in 20 large and local systems.

In order to increase the quality of the countryside and to promote sustainable farming systems, one has to protect the soil through both, the rehabilitation and / or extension of the existing barren hydro-ameliorative works, as well as by resizing the plots of the agricultural exploitations.

The pipe drainage system with spacing between drain lines of $12-15 \mathrm{~m}$ and of maximum 20 $\mathrm{m}$ resulted to be an efficient solution for the proper evacuation of excess water.

The process of removal of the excess water from the surface of the soil and/or within the soil, water that resulted from the rainfalls of $40-160 \mathrm{~mm}$, which fell in periods of $1-5$ consecutive days, was made in the conditions that were studied with the specific water flow of $1.5-2.51 \cdot \mathrm{s}^{-1} \cdot \mathrm{ha}^{-1}$.

The growth of the spacing between the drain lines with up to 20 - $30 \mathrm{~m}$ must be associated to the agro- and soil improvement: periodically deep loosening works, mole drainage and land shaping in the bedding system with ridges and furrows.

Classification and evaluation of soil quality for usages and crops is the database of qualitative farm cadastre at the level of soil-field mapping units of soil.

For the natural conditions of albic stagnic-glossic Luvosol from the Baia Depression, we have estimated an average classification mark of 39 points for grasslands and hayfields and of 13 points for the arable land, with extremely severe limitations caused by water excess.

By the arrangement of the farm field for water excess removal and the corresponding application of agro-soil ameliorative works, we have achieved the "increase" of some classification indicators, obtaining an average mark of 84 points for "improved pastures" and 64 points for "arable land".

\section{Acknowledgment}

This work was supported by CNCSIS - UEFISCSU, project number PNII - IDEI 1132 / 2008.

\section{References}

Canarache A. (1990). Fizica solurilor agricole. Ceres. Bucharest.

Canarache, A. (1991). Factors and indices regarding excessive compactness of agricultural soils. Soil \& Tillage Research. Elsevier Science B.V. Publishers, 19: 145-164. Amsterdam.

Cooke, R.A., Sands, G.R., Brown, L.C. (2002). Drainage water management: a practice for reducing nitrate loads from subsurface drainage systems. ASAE Publication, Paper No 05. St. Joseph, Mich; 8 pp. 
Dumitru, M, Ciobanu, C., Manea, Alexandrina, Gament ,Eugenia, Risnoveanu, I., Mihalache, Daniela, Tanase, Veronica, Vrinceanu, Nicoleta, Calciu, Irina, Balaceanu, Claudia, Preda, Mihaela. (2004). The evolution of main parameters of soil and agricultural lands in Romania. Soil Science National Conference. 36 A (1). pp. 39-68. Solness, Timisoara.

Florea, N., Munteanu, I. (2003). Romanian System of Soil Taxonomy, Estfalia, Bucharest, pp. 30-98.

Jitareanu, G., Rusu, C., Moca, V. (2009). Evaluation and use of soil resources, environmental protection and rural development in the north-eastern part of Romania, Ion Ionescu de la Brad, Iasi, pp. 57-63.

Lukianas, A., Vaikasas, S., Malisauskas, A. (2006). Water management tasks in the summer polders of the Nemunas Lowland. Irrigation and drainage. 55 (2): 145-156. DOI: 10.1002/ird.230.

Man, T. E., Stoica, Fl. (2002). Amenajarea terenurilor cu exces de umiditate din vestul şi nord-vestul țării. Sesiune Stiintifica Internatională Aniversara, Bucharest, pp. 169174, Bren. Bucureşti.

Mejia, M.N., Madramootoo, C.A. (1998). Improvement water quality through water table management in eastern Canada. Journal of Irrigation and Drainage Engineering. 124(2). pp. 116-122.

Mirsal, A.I. (2004). Soil pollution. Origin, monitoring \& remediation. Springer. Berlin.

Moca, V., Canarache, A., Dumitru, Elisabeta. (1988). Modificari agrofizice ale Luvosolului albic, pseudogleic, drenat si cultivat intensiv in conditiile zonei umede din Depresiunea Baia-Moldova. Lucrarile Conferintei Nationale pentru Stiinta Solului. 26 A (1). pp. 63-76. Bucharest

Moca, V., Bofu, C., Filipov, F., Radu, O. (2001). Influenta de lunga durata a drenajului subteran si a unor lucrari ameliorative asupra solului din campul de drenaje agricole Baia-Moldova. Lucrarile Conferintei Nationale pentru Stiinta Solului. 30A (1). pp. 90-110. Bucharest

Munteanu, I., Dumitru, M., Florea, N., Canarache, A., Lacatusu, R., Vlad, V., Simota, C., Ciobanu, C., Rosu, C. (2004). Status of Soil Mapping, Monitoring, and Database Compilation in Romania at the beginning of the 21st century, European Soil Bureau Research Report, 9, ISPRA Italy, pp. 251-266.

Ramoska, E., Bastiene, N., Saulys, V. (2011). Evaluation of controlled drainage efficiency in Lithuania. Irrigation and drainage. 60 (2). pp. 196-206

Ritzema, H.P., Kselik, R.A.L., Chanduvi, F. (1996). Drainage of irrigated lands: a manual (Irrigation water management training manual). Rome: FAO

Singh V, Frevert D, Rieker J, Leverson V, Meyer Susan, Meyer St. (2006). Hydrologic modeling inventory: cooperative research effort. Journal of Irrigation and Drainage Engineering. 132 (2): 98-103. DOI: 10.1061/(ASCE)0733-9437(2006)132:2(98)

Someren, C.L. van. (1964). De toepassing van plastieken draineerbuizen in Nederland. Cultuurtechniok, 2 Jarg. 1-3. Rotterdam.

Townend, J., Reeve, M.J., Carter, A. (2001). Water release characteristics. In: Soil and environmental analysis: Physical methods (2nd ed.), Smith K. A., Mullins C. E. (eds.). New York: Marcel Decker Inc.

Troeh, F.R., Thomson, L.M. (2005). Soils and soil fertility. Iowa: Blackwell Publisher. 
Walker, W.R. (1989). Guidelines for designing and evaluating surface irrigation systems, FAO Irrigation and Drainage Paper (FAO). 45. Rome

***. (1987). Methodology of soil studies elaboration. National Institute of Research and Development in Soil Science, Agrochemistry and Environment. Bucharest, vol. I, p. 135-154,

***. (2006). World reference base for soil resources 2006. World Soil Resources Reports. 103. FAO. Rome.

***. (2008). Romanian Statistical Yearbook. National Institute of Statistics. Bucharest.

***. (2010). Romanian Statistical Yearbook. National Institute of Statistics. Bucharest. 


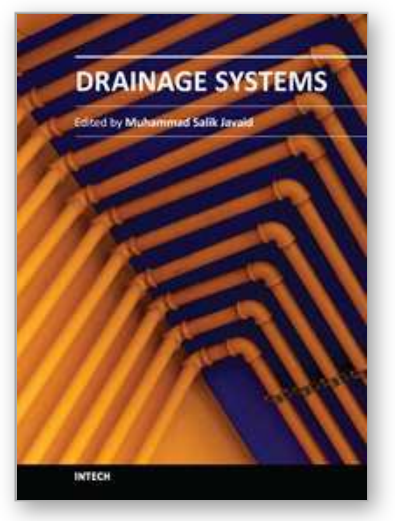

\author{
Drainage Systems \\ Edited by Prof. Muhammad Salik Javaid
}

ISBN 978-953-51-0243-4

Hard cover, 240 pages

Publisher InTech

Published online 07, March, 2012

Published in print edition March, 2012

The subject of 'drainage: draining the water off' is as important as 'irrigation: application of water', if not more. 'Drainage' has a deep impact on food security, agricultural activity, hygiene and sanitation, municipal usage, land reclamation and usage, flood and debris flow control, hydrological disaster management, ecological and environmental balance, and water resource management. 'Drainage Systems' provides the reader with a tridimensional expose of drainage in terms of sustainable systems, surface drainage and subsurface drainage. Ten eminent authors and their colleagues with varied technical backgrounds and experiences from around the world have dealt with extensive range of issues concerning the drainage phenomenon. Field engineers, hydrologists, academics and graduate students will find this book equally benefitting.

\title{
How to reference
}

In order to correctly reference this scholarly work, feel free to copy and paste the following:

Daniel Bucur and Valeriu Moca (2012). Tile Drainage on Agricultural Lands from North- East Romania Experimental Variants and Technical Efficiency, Drainage Systems, Prof. Muhammad Salik Javaid (Ed.), ISBN: 978-953-51-0243-4, InTech, Available from: http://www.intechopen.com/books/drainage-systems/tile-drainageon-agricultural-lands-from-north-east-romania-experimental-variants-and-technical-effi

\section{INTECH}

open science | open minds

\section{InTech Europe}

University Campus STeP Ri

Slavka Krautzeka 83/A

51000 Rijeka, Croatia

Phone: +385 (51) 770447

Fax: +385 (51) 686166

www.intechopen.com
InTech China

Unit 405, Office Block, Hotel Equatorial Shanghai

No.65, Yan An Road (West), Shanghai, 200040, China

中国上海市延安西路65号上海国际贵都大饭店办公楼405单元

Phone: $+86-21-62489820$

Fax: +86-21-62489821 
(C) 2012 The Author(s). Licensee IntechOpen. This is an open access article distributed under the terms of the Creative Commons Attribution 3.0 License, which permits unrestricted use, distribution, and reproduction in any medium, provided the original work is properly cited. 